\title{
New national and regional bryophyte records, 52
}

L. T. Ellis, M. Alataş, M. Aleffi, A. Alegro, V. Šegota, S. Ozimec, N. Vuković, N. Koletić, D. Prlić, M. Bontek, A. K. Asthana, D. Gupta, V. Sahu, K. K. Rawat, V. A. Bakalin, K. G. Klimova, K. Baráth, L. N. Beldiman, J. Csiky, J. Deme, D. Kovács, M. J. Cano, J. Guerra, I. V. Czernyadjeva, M. V. Dulin, P. Erzberger, T. Ezer, V. E. Fedosov, S. Fontinha, M. Sim-Sim, C. A. Garcia, A. Martins, I. Granzow-de la Cerda, L. Sáez, K. Hassel, H. Weibull, N. G. Hodgetts, M. Infante, P. Heras, T. Kiebacher, J. Kučera, M. Lebouvier, R. Ochyra, M. Ören, B. Papp, S. J. Park, B.-Y. Sun, V. Plášek, S. Poponessi, R. Venanzoni, D. Purger, F. Reis, M. Singila, A. Stebel, S. Ştefănuţ, G. Uyar, G. Vončina, M. J. Wigginton, K.-T. Yong, M. S. Chan \& Y.-J. Yoon

To cite this article: L. T. Ellis, M. Alataș, M. Aleffi, A. Alegro, V. Šegota, S. Ozimec, N. Vuković, N. Koletić, D. Prlić, M. Bontek, A. K. Asthana, D. Gupta, V. Sahu, K. K. Rawat, V. A. Bakalin, K. G. Klimova, K. Baráth, L. N. Beldiman, J. Csiky, J. Deme, D. Kovács, M. J. Cano, J. Guerra, I. V. Czernyadjeva, M. V. Dulin, P. Erzberger, T. Ezer, V. E. Fedosov, S. Fontinha, M. SimSim, C. A. Garcia, A. Martins, I. Granzow-de la Cerda, L. Sáez, K. Hassel, H. Weibull, N. G. Hodgetts, M. Infante, P. Heras, T. Kiebacher, J. Kučera, M. Lebouvier, R. Ochyra, M. Ören, B. Papp, S. J. Park, B.-Y. Sun, V. Plášek, S. Poponessi, R. Venanzoni, D. Purger, F. Reis, M. Singila, A. Stebel, S. Ștefănuț, G. Uyar, G. Vončina, M. J. Wigginton, K.-T. Yong, M. S. Chan \& Y.-J. Yoon (2017): New national and regional bryophyte records, 52, Journal of Bryology, DOI: 10.1080/03736687.2017.1341752

To link to this article: http://dx.doi.org/10.1080/03736687.2017.1341752 

records, 52

L. T. Ellis ${ }^{1}$, M. Alataș ${ }^{2}$, M. Aleffi ${ }^{3}$, A. Alegro $^{4}$, V. Šegota ${ }^{4}$, S. Ozimec ${ }^{4}$, N. Vuković ${ }^{4}$, N. Koletić ${ }^{4}$, D. Prlić ${ }^{4}$, M. Bontek ${ }^{4}$, A. K. Asthana ${ }^{5}$, D. Gupta ${ }^{5}$, V. Sahu ${ }^{5}$, K. K. Rawat ${ }^{5}$, V. A. Bakalin ${ }^{6}$, K. G. Klimova ${ }^{6}$, K. Baráth ${ }^{7}$, L. N. Beldiman ${ }^{8}$, J. Csiky ${ }^{9}$, J. Deme ${ }^{9}$, D. Kovács ${ }^{9}$, M. J. Cano $^{10}$, J. Guerra ${ }^{10}$, I. V. Czernyadjeva ${ }^{11}$, M. V. Dulin ${ }^{12}$, P. Erzberger ${ }^{13}$, T. Ezer $^{14}$, V. E. Fedosov ${ }^{15}$, S. Fontinha ${ }^{16}$, M. Sim-Sim ${ }^{16,17}$, C. A. Garcia ${ }^{17}$, A. Martins ${ }^{17}$, I. Granzow-de la Cerda $^{18}$, L. Sáez ${ }^{18}$, K. Hassel ${ }^{19}$, H. Weibull ${ }^{19}$, N. G. Hodgetts ${ }^{20}$, M. Infante ${ }^{21}$, P. Heras ${ }^{21}$, T. Kiebacher ${ }^{22}$, J. Kučera ${ }^{23}$, M. Lebouvier ${ }^{24}$, R. Ochyra ${ }^{25}, M$. Ören ${ }^{26}$, B. Papp ${ }^{27}$, S. J. Park ${ }^{28}$, B.-Y. Sun ${ }^{28}$, V. Plášek ${ }^{29}$, S. Poponessi $i^{30}$, R. Venanzoni ${ }^{30}$, D. Purger ${ }^{31}$, F. Reis ${ }^{32}$, M. Singila ${ }^{33}$, A. Stebel ${ }^{34}$, S. Ştefănuţ ${ }^{35}$, G. Uyar ${ }^{36}$, G. Vončina ${ }^{37}$, M. J. Wigginton ${ }^{38}$, K.-T. Yong ${ }^{39}$, M. S. Chan ${ }^{39}$, Y.-J. Yoon ${ }^{40}$

${ }^{1}$ The Natural History Museum, London, UK, ${ }^{2}$ Tunceli University, Tunceli, Turkey, ${ }^{3}$ University of Camerino, Camerino (MC), Italy, ${ }^{4}$ Department of Botany, University of Zagreb, Zagreb, Croatia, ${ }^{5}$ CSIR-National Botanical Research Institute, Lucknow, India, ${ }^{6}$ Botanical Garden-Institute, Vladivostok, Russia, ${ }^{7}$ Institute of Biology, University of West Hungary, Szombathely, Hungary, ${ }^{8}$ Russian Arctic National Park, Arkhangelsk Oblast, Russia, ${ }^{9}$ Institute of Biology, University of Pécs, Pécs, Hungary, ${ }^{10}$ Universidad de Murcia, Murcia, Spain, ${ }^{11}$ Komarov Botanical Institute of Russian Academy of Science, St Petersburg, Russia, ${ }^{12}$ Institute of Biology Komi Science Centre, Syktyvkar, Komi Republic, Russia, ${ }^{13}$ Berlin, Germany, ${ }^{14}$ Department of Biology, Ömer Halisdemir University, Niğde, Turkey, ${ }^{15}$ Lomonosov Moscow State University, Moscow, Russia, ${ }^{16}$ Centre for Ecology, Evolution and Environmental Changes, Universidade de Lisboa, Lisboa, Portugal, ${ }^{17}$ Museu Nacional de História Natural e da Ciência, Universidade de Lisboa, Lisboa, Portugal, ${ }^{18}$ Universitat Autònoma de Barcelona, Barcelona, Spain, ${ }^{19}$ University Museum, Norwegian University of Science and Technology, Trondheim, Norway, ${ }^{20}$ Portree, Isle of Skye, UK, ${ }^{21}$ Museo de Ciencias Naturales de Álava, Vitoria-Gasteiz, Spain, ${ }^{22}$ Swiss Federal Research Institute WSL, Birmensdorf, Switzerland, ${ }^{23}$ University of South Bohemia, České Budějovice, Czech Republic, ${ }^{24}$ CNRS UMR 6553, Université de Rennes 1, Rennes, Paimpont, France, ${ }^{25}$ W. Szafer Institute of Botany, Polish Academy of Sciences, Kraków, Poland, ${ }^{26}$ Bülent Ecevit University, Zonguldak, Turkey, ${ }^{27}$ Hungarian Natural History Museum, Budapest, Hungary, ${ }^{28}$ Chonbuk National University, Jeonju, Korea, ${ }^{29}$ University of Ostrava, Ostrava, Czech Republic, ${ }^{30}$ University of Perugia, Perugia, Italy, ${ }^{31}$ BioRes, Pécs, Hungary, ${ }^{32}$ Banco de Germoplasma ISOPlexis, Universidade da Madeira, Funchal, Madeira, Portugal, ${ }^{33}$ Bakony Museum of the Hungarian Natural History Museum, Zirc, Hungary, ${ }^{34}$ Department of Pharmaceutical Botany, Medical University of Silesia in Katowice, Sosnowiec, Poland, ${ }^{35}$ Institute of Biology Bucharest of Romanian Academy, Bucharest, Romania, ${ }^{36}$ Gazi University, Ankara, Turkey, ${ }^{37}$ Pieniny National Park, Krościenko nad Dunajcem, Poland, ${ }^{38}$ Warmington, UK, ${ }^{39}$ Institute of Biological Sciences, University of Malaya, Kuala Lumpur, Malaysia, ${ }^{40}$ Korea Polar Research Institute, Incheon, Korea

1. Acrobolbus ciliatus Mitt.

Contributors: D. Gupta, K. K. Rawat, V. Sahu and A. K. Asthana

India: Uttarakhand, Uttarkashi, Govind Wildlife Sanctuary, between Badang and Daldhar, Vijay top,

Correspondence to: L. T. Ellis, Department of Life Sciences, The Natural History Museum, Cromwell Road, London SW7 5BD, UK. Email: I.ellis@ nhm.ac.uk $31^{\circ} 08.862^{\prime} \mathrm{N}, 78^{\circ} 10.738^{\prime} \mathrm{E}, 3580 \mathrm{~m}$ a.s.1., on soil, 08 October 2015, leg. K. K. Rawat 300492 (LWG).

Acrobolbus ciliatus has been recorded in India from eastern Himalayan localities in Sikkim (East and West Sikkim) and West Bengal (Phalut and Tiger Hill) (Hattori, 1966; Srivastava et al., 1995; Singh et al., 2016). The present report from Uttarakhand is the first from the western Himalayan region of India. 
Plants in the collection were scattered among other bryophytes, light green, up to $13 \mathrm{~mm}$ long and $1.9 \mathrm{~mm}$ wide, with intercalary branching. Underleaves were absent and rhizoids were scattered along the ventral surface. The stems were slender, delicate, round in cross-section and 8-9 cells wide with a single layer of quadrangular, slightly thickened cortical cells and thin-walled medullary cells with indistinct trigones. The leaves were succubous, distant to loosely imbricate, oblong-quadrate, $\quad 0.55-0.70 \times 0.60-0.65 \mathrm{~mm}$, with the ventral lobe larger than dorsal lobe and an acute sinus. Leaf margins were usually entire, but occasionally possessed a few, long, unicellular cilia, and laminal cells were thin-walled with distinct trigones. Those at the margin were quadrangular, whilst the median and basal cells were polygonal. Fertile plants not observed.

\section{Biantheridion undulifolium (Nees) Konstant. \&} Vilnet

Contributor: M. V. Dulin

Russian Federation: (1) Komi Republic, Northern Urals, Vuktylsky district, "Yugyd Va" National Park, the Shchugor River basin, near the Halmersale Mountain, $4.5 \mathrm{~km}$ south-west of the confluence of the main feeders into the Halmerya River, $63^{\circ}$ $48^{\prime} 04.3^{\prime \prime} \mathrm{N}, 59^{\circ} 12^{\prime} 57.8^{\prime \prime} \mathrm{E}$, ca $707 \mathrm{~m}$ a.s.l., on a terrace above $610.8 \mathrm{~m}$ a.s.1., wet Carex-EriophorumSphagnum depressions in dwarf shrub-moss-lichen tundra, on Sphagnum hummock, among Neoorthocaulis binsteadii (Kaal.) L.Söderstr., De Roo \& Hedd. with other liverworts, Cephalozia pleniceps (Austin) Lindb. and Lophozia ventricosa (Dicks.) Dumort., male plants with androecium, 12 July 2016, leg. \& det. M.V. Dulin 23ha=1257mvd (SYKO); (2) Komi Republic, Northern Urals, Vuktylsky district, "Yugyd Va" National Park, the Shchugor River basin, near the Halmersale Mountain, $2.7 \mathrm{~km}$ southwest of the confluence of the main feeders into the Halmerya River, $63^{\circ} 48^{\prime} 14.3^{\prime \prime} \mathrm{N}, 5^{\circ} 15^{\prime} 13.6^{\prime \prime} \mathrm{E}$, ca 505 $\mathrm{m}$ a.s.l., complex undulating mire between streams, dwarf shrub-moss-lichen slope of hillock, scattered plants among Sphagnum fuscum (Schimp.) Klinggr. and on the dead Sphagnum among Lophozia ventricosa (Dicks.) Dumort. with other liverworts, Neoorthocaulis binsteadii and Mylia anomala (Hook.) Gray, 6 July 2016, leg. \& det. M.V. Dulin 13_a_ha=1247mvd (SYKO).

This is the first report of Biantheridion undulifolium [三 Crossogyna undulifolia (Nees) Schljakov] from the Komi Republic. It is an arcto-boreal-montane species with a disjunctive distribution (Konstantinova, 2000). This liverwort was formerly a Critically Endangered species included in the Red Data Book of European Bryophytes (ECCB, 1995). The conservation status of this species has now changed to Vulnerable (Bryophyte Specialist Group, 2000).
Biantheridion undulifolium is known from several countries in Europe (Austria, United Kingdom, Czech Republic, Denmark, Finland, France, Germany, Switzerland, Norway, Poland, Sweden) and from some localities in North America (Baffin I, Greenland) (Damsholt, 2002; Schumacker \& Váňa, 2005). It has also been reported from several countries in Asia, including China (Piippo, 1990) and Korea (Yamada \& Choe, 1997). In Russia, it is recorded from the Yamal-Nenets Autonomous District (Polar Ural), Khanty-Mansi Autonomous District (Subpolar Ural), Bashkortostan Republic (Southern Urals), Kemerovskaia Province (Kuznetskij Alatau Range), Yakutia Republic (Suntar-Khayata, Udokan and Orulgan Ranges), Irkutsk Province (Udokan Range), Buryatia Republic (Khamar-Daban Range), Chukchi Autonomous District (Chukotka Peninsula, Koryakskiy Range, Wrangel Island), Sakhalin Province (Piltun Bay) (Konstantinova et al., 2009; Potemkin \& Sofronova, 2009; Bakalin, 2010; Bakalin et al., 2012; Konstantinova \& Lapshina, 2014). The report of this species by Damsholt (2002) from Kamchatka is erroneous. Biantheridion undulifolium was recorded in the Red Data Books of some regions of Russia, e.g. Chukchi Autonomous District (Chereshnev, 2008) and Bashkortostan Republic (Mirkin, 2011).

\section{Brachythecium rutabulum (Hedw.) Schimp.}

Contributors: R. Ochyra and M. Lebouvier

Îles Crozet, Île de la Possession: (1) eastern coast, Pointe Lieutard, rock outcrops $200 \mathrm{~m}$ south of the Alfred Faure Station by the road toward the penguin rookery at Baie du Marin, $46^{\circ} 26.125^{\prime} \mathrm{S}, 51^{\circ} 51.510^{\prime} \mathrm{E}$, $80 \mathrm{~m}$ a.s.1., in fernbrake under the canopy of Blechnum penna-marina (Poir.) Kuhn in a shady and fairly damp situation, 9 November 2006, leg. R. Ochyra 21/06 (with M. Lebouvier) (KRAM); (2) eastern coast, in the valley of the Rivière du Camp, north of the Alfred Faure Station, $46^{\circ} 25^{\prime} 20^{\prime \prime} \mathrm{S}, 51^{\circ}$ $50^{\prime} \mathrm{E}, 60 \mathrm{~m}$ a.s.1, on ground in fernbrake on slope above the stream, associated with Sanionia uncinata (Hedw.) Loeske, 10 November 2006, leg. R. Ochyra 86/06 (with M. Lebouvier) (KRAM); (3) eastern coast, a small stream $300 \mathrm{~m}$ south-east of the Alfred Faure Station falling into the small cove south of Pointe Lieutard, $46^{\circ} 25^{\prime} 40^{\prime \prime} \mathrm{S}, 51^{\circ} 50^{\prime} \mathrm{E}, 100 \mathrm{~m}$ a.s.1, in fernbrake in shady situation, on slope above the stream with the dam, 11 November 2006, leg. R. Ochyra 151/06 \& 163/06 (with N. Van der Putten) (KRAM); (4) eastern coast, on plateau $2 \mathrm{~km}$ south of the Alfred Faure Station and $2 \mathrm{~km}$ south-

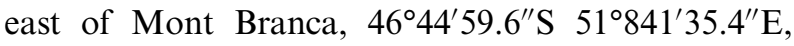
$185 \mathrm{~m}$ a.s.1., on ground in stand of Blechnum pennamarina in dry and shaded places, 11 November 2006, leg. R. Ochyra 190/06 (with M. Lebouvier and N. Van der Putten) (KRAM); (5) without any detailed 
locality data, 'Crozet Island, 1907-1908, leg. Ring \& Raknes 43c' (BG-Kaalaas as Brachythecium rivulare Schimp.).

Brachythecium rutabulum is a bipolar species with some intermediate stations in tropical mountains in the Americas, East Africa and in the Hawaiian Islands in the Pacific Ocean. In the northern hemisphere it is widespread in the temperate regions in North America and Eurasia extending southwards to Macaronesia and North Africa. Outside the Holarctic it is widely distributed but scattered in the Americas occurring along the Cordillera from the Central American isthmus (Guatemala, Costa Rica), through the tropical northern and Central Andes of Colombia, Ecuador, Peru and Bolivia (McFarland, 1988) to temperate southern South America where it occurs in Chile from Talca Province in the VII Région Maule to Magallanes and Antárctica Chilena in the Région XII Magallanes (Müller, 2009). In contrast, it is very rare in Ethiopia and Tanzania in sub-Saharan East Africa (O'Shea, 2006). In the southern hemisphere, apart from southern South America, it is frequent in New Zealand (Sainsbury, 1955), SE Australia (Streimann \& Klanzenga, 2002) and on some subantarctic islands, including Macquarie Island (Seppelt, 2004), Îles Kerguelen (McFarland, 1988) and the Prince Edward Islands (Zanten, 1971). The subantarctic range of this species is completed by its present discovery on Île de la Possession, the largest island of the Îles Crozet archipelago. Like other islands of this archipelago, it is of volcanic origin and emerged above sea level about eight million years ago. The island was once thought to have been heavily glaciated during the Last Glacial Maximum (LGM) and the ice-sheet was believed to have covered the plateau and the rest of the island down to sea level, although ice-free refugia were apparently present during the LGM. Therefore, its present plant and animal inhabitants may be relative newcomers, as is the case on other sub-Antarctic (Van der Putten et al., 2004, 2009, 2010) and Antarctic islands (Birkenmajer et al., 1985).

The present discovery of Brachythecium rutabulum is an interesting addition to the moss flora of Îles Crozet. For a long time it was the least studied group of islands in the Subantarctic, but in recent decades a number of species have been discovered in this archipelago (e.g. Blockeel et al., 2006, 2007; Ochyra \& Bednarek-Ochyra, 2013; BednarekOchyra, 2014a; Ellis et al., 2014a, 2014b, 2015a, 2015b, 2016b, 2016c, 2016d), which has increased the moss flora to well over 70 species. Brachythecium rutabulum was actually collected for the first time in Îles Crozet by the Norwegian sealing voyage of 1907-1908 on the ship Solglimt, under the command of Captain Anders Harboe Ree. A small collection of mosses was made by Th. Ring and O. Raknes, which was studied by Kaalaas (1912), who reported $B$. rivulare Schimp. from this archipelago, unfortunately, without indicating the island or any locality data. This author suggested that possibly the material represented a new variety of $B$. rivulare since it deviated from European plants, among others, in having a longer leaf apex and more strongly serrate and plicate leaves. In fact, these plants fall quite well within the range of variation of subantarctic populations of $B$. rutabulum as known from other islands in the Kerguelen Biogeographical Province. Accordingly, B. rivulare has to be definitely excluded from the moss flora of the Subantarctic.

\section{Bryum gemmiferum R.Wilczek \& Demaret}

Contributors: K. Hassel and H. Weibull

Norway: Rogaland county, Rennesøy municipality, Mosterøy, Steinsvoll. 59.08239 ${ }^{\circ} \mathrm{N}, 5.65972^{\circ} \mathrm{E}, 23 \mathrm{~m}$ a.s.l. Barley stubble field on brown soil with gravel, 24 October 2012, leg. K. Hassel, Henrik Weibull, John Bjarne Jordal, Maria Lima, Leif Appelgren and John Inge Johnsen (TRH-773192).

Mosterøy in SW Norway is an area with a long history of settlement and agriculture, and is situated in one of the most intensive agricultural areas of Norway. Bryum gemmiferum was found growing in small scattered patches in a stubble field. Associated species were: Ceratodon purpureus (Hedw.) Brid., Riccia sorocarpa Bisch., Bryum argenteum Hedw., Atrichum tenellum (Röhl.) Bruch \& Schimp., Trichodon cylindricus (Hedw.) Schimp., Tortula truncata (Hedw.) Mitt., Bryum rubens Mitt., Funaria hygrometrica Hedw., Oxyrrhynchium hians (Hedw.) Loeske and Bryum dichotomum Hedw.

The species was described based on material from Hooglede, Flanders in Belgium in 1976 (Wilczek \& Demaret, 1976) and is widely distributed in Europe from the Mediterranean in the south to Scandinavia in the north (Ellis et al., 2016d). In addition it is known from the Canary Islands and North America (Spence, 2015).

Increased focus on arable fields in Norway has led to several new records of species occurring in this habitat over the last two decades (e.g. Hassel, 2003, 2004; Høitomt et al., 2012).

5. Bucklandiella chlorocarpa (Paris) Bednarek-Ochyra \& Ochyra

Contributors: R. Ochyra and V. Plášek

New Zealand, Stewart Island (Rakiura): Oban, the main port on the north-east side of the island, on a side branch of Main Road leading to Ferns Gully, $46^{\circ} 53.766^{\prime} \mathrm{S}, 168^{\circ} 06.947^{\prime} \mathrm{E}, 20 \mathrm{~m}$ a.s.1., on wet boulder in stream, associated with Bucklandiella crispula (Hook.f. \& Wilson) Bednarek-Ochyra \& Ochyra, 2 March 2013, leg. H. Bednarek-Ochyra, R. Ochyra \& V. Plášek 2425A/13 (KRAM). 
Bucklandiella chlorocarpa has long been a poorly known, neglected species and has a chequered taxonomic and nomenclatural history (Bednarek-Ochyra, 2015a). Although the epithet 'chlorocarpa' appeared in the literature relatively early, the binomial Grimmia chlorocarpa Mitt. was not validly published (Mitten, 1876a, 1876b, 1882), as was also the case with Racomitrium chlorocarpum Mitt. ex Hook.f. (Hooker, 1867), Dryptodon chlorocarpus Mitt. ex F.Muell. (Mueller, 1881) and Racomitrium chlorocarpum Mitt. ex Bastow (Bastow, 1887). The species was first recognised by Hooker (1867) as an unnamed variety of Racomitrium crispulum (Hook.f. \& Wilson) Wilson, which was subsequently raised to species by Paris (1897) as $R$. chlorocarpum Paris.

Bucklandiella chlorocarpa is a rheophytic moss growing on rocks, often submerged, in stream beds and cascades with quickly flowing water. The species has a number of adaptations to rheophytic habitats, including massive costae, thick, few-layered laminal cells and strongly thickened marginal limbidia, which protect the plants against the destructive action of water currents. These adaptations are known in many mosses occupying such sites (Ochyra, 1985a, 1985b, 1986, 1987; Sérgio et al., 1995; Ochyra \& Vanderpoorten, 1999; Ochyra \& Bednarek-Ochyra, 2011). Bucklandiella chlorocarpa shares these characters with B. lamprocarpa (Müll.Hal.) BednarekOchyra \& Ochyra, which occupies similar sites in southern South America, where it penetrates to the central and northern Andes (Blockeel et al., 2002; Bednarek-Ochyra, 2014b, 2015b), South and East Africa (Bednarek-Ochyra \& Ochyra, 2012a; Ochyra \& van Rooy, 2013) and to some islands in the Southern Ocean (Ochyra et al., 1988; BednarekOchyra \& Ochyra, 1998). The same features are also shown by many populations of $B$. orthotrichacea (Müll.Hal.) Bednarek-Ochyra \& Ochyra, an amphiatlantic south-temperate species occurring in the Nothofagus zone in southern South America and on some subantarctic islands in the Kerguelen Biogeographical Province (Bednarek-Ochyra \& Ochyra, 2012b; Bednarek-Ochyra, 2014c).

Bucklandiella chlorocarpa is an Australasian endemic known from Tasmania and the two main islands of New Zealand (Bednarek-Ochyra, 2015a; Ellis et al., 2017). Herein, it is recorded for the first time from Stewart Island (also called Rakiura in the Maori language), the third largest island of New Zealand, which is situated $30 \mathrm{~km}$ south of the South Island, across the Foveaux Strait, and this is the southernmost station of the species. The species was collected on boulders in a stream-bed growing in a mixed stand together with $B$. crispula with which it shares the presence of bistratose limbidia and long basal marginal borders of pellucid cells with straight walls. However, B. crispula has smooth capillaceous hair-points, $0.2-0.6 \mathrm{~mm}$, which are yellow to yellowish-brown throughout, or often possess hyaline tips. In contrast, $B$. chlorocarpa has a serrate, broad and massive hair-point, to $0.2 \mathrm{~mm}$, that is never hyaline. It shares the shape of the hair-points with $B$. didyma (Mont.) Bednarek-Ochyra \& Ochyra and the sterile material of $B$. chlorocarpa, such as collected on Stewart Island, may be distinguished only on the basis of the ecological predilections of the plants. Bucklandiella didyma grows on dry rocks and has never been observed in rheophytic habitats (Ochyra et al., 2015).

Bucklandiella Roiv. is a prominent genus in the moss flora of New Zealand and consists of 12 species (Bednarek-Ochyra et al., 2014; Bednarek-Ochyra, 2015c). Four of these are local endemics and they have been discovered and described only in recent decades, namely B. crumiana (Fife) BednarekOchyra \& Ochyra, B. curiosissima (Bednarek-Ochyra \& Ochyra) Bednarek-Ochyra \& Ochyra, B. allanfifei Bednarek-Ochyra \& Ochyra and B. angustissima (Fife, 1984; Bednarek-Ochyra \& Ochyra, 1996, 2010, 2011), whilst the other four are Australasian endemics, namely $B$. crispula, B. chlorocarpa, B. pycnotricha (Müll.Hal.) Bednarek-Ochyra \& Ochyra and B. seppeltii Bednarek-Ochyra \& Ochyra, Sawicki \& Szczecińska, occurring additionally in Tasmania and on mainland Australia.

6. Bucklandiella microcarpa (Hedw.) BednarekOchyra \& Ochyra

Contributors: V. E. Fedosov and L. N. Beldiman

Russia: Novaya Zemlya Archipelago, gentle slope on the north-eastern shore of Northern Island, between Pospelova Bay and Natalii Bay, $76^{\circ}$ $51.958^{\prime} \mathrm{N}, 68^{\circ} 33.14^{\prime} \mathrm{E}$, ca $140 \mathrm{~m}$ a.s.l., in open herb and moss dominated community on gravely barren ground with Stellaria crassipes Hultén, Cerastium regelii Ostenf., Poa abbreviata R.Br., Saxifraga cernua L., Niphotrichum ericoides (Brid.) BednarekOchyra \& Ochyra, Racomitrium lanuginosum (Hedw.) Brid., Polytrichum juniperinum Hedw., Flexitrichum flexicaule (Schwägr.) Ignatov \& Fedosov, Hymenoloma crispulum (Hedw.) Ochyra, Pohlia cruda (Hedw.) Lindb., Warnstorfia sarmentosa (Wahlenb.) Hedenäs, etc., few plants; 30 July 2016, leg. L.N. Beldiman s.n. (MW).

According to Frisvoll (1988) this widespread species has a northern circumboreal distribution, though the map provided in that paper demonstrated clear disjunctions in xeric areas of northern Asia and North America. The species penetrates to the Arctic, reaching the 70th latitude mostly in the Atlantic sector, and remains unknown in any of the Arctic archipelagos. Thus, this newly discovered locality for the species in the northern extremity of the Novaya 
Zemlya Archipelago was quite unexpected. This is the first locality for B. microcarpa in archipelagoes of the Arctic Ocean and in the High Arctic.

7. Buxbaumia aphylla Hedw.

Contributors: J. Deme, A. Alegro, D. Kovács, D. Purger, V. Šegota and J. Csiky

Croatia: (1) Papuk Mt, Sokolina, in the vicinity of Doljanci, $538 \mathrm{~m}$ a.s.1., $45.49391^{\circ} \mathrm{N}, 17.60756^{\circ} \mathrm{E}$, on acidic soil, 18 July 2015, leg./det. Deme, J., Csiky, J., Kovács, D. \& Purger, D. s.n. (JPU), repeated collection on 16th October 2015, leg. Alegro, A. \& Šegota, V. s.n. (ZA); (2) Papuk Mt, Svinjarevac, in the vicinity of Kamenski Vučjak, $354 \mathrm{~m}$ a.s.1., $45.51063^{\circ} \mathrm{N}$, $17.53189^{\circ} \mathrm{E}$, on acidic soil and Sphagnum peat, 12 July 2016, leg./det. Csiky, J., Deme, J., Kovács, D. \& Purger, D. s.n. (JPU); (3) Papuk Mt, Konjska smrt, north-west from Leštat, in the vicinity of Kamenski Vučjak, $353 \mathrm{~m}$ a.s.1., $45.50800^{\circ} \mathrm{N}$, $17.53691^{\circ} \mathrm{E}$, on acidic soil, 12 July 2016 , leg./det. Csiky, J., Deme, J., Kovács, D. \& Purger, D. s.n. (JPU).

This circumpolar boreal-montane moss (Hill \& Preston, 1998) is a new species for Croatia. In the surrounding countries B. aphylla occurs in BosniaHerzegovina (LC), Hungary (VU), Montenegro (EN) and Slovenia (LC), but it was not observed in Serbia (Hodgetts, 2015). We have found 58 capsules and 12 setae at the three sites: the smallest population (10 specimens) was located at Sokolina; at the two other sites $B$. aphylla was more abundant (Svinjarevac: 29 specimens, Konjska smrt: 31 specimens). The species occurred on bare acidic soil or on Sphagnum peat, under the shade of beech or sessile oak trees. In six sampling plots $\left(1 \mathrm{~m}^{2}\right)$ the most frequent $(\geq 50 \%)$ associated species in the moss and lichen layer were Cladonia spp. (incl. Cl. fimbriata (L.) Fr., Cl. furcata (Huds.) Schrad., Cl. gracilis (L.) Willd. and $\mathrm{Cl}$. squamosa (Scop.) Hoffm.), Dicranella heteromalla (Hedw.) Schimp., Dicranum scoparium Hedw., Diphyscium foliosum (Hedw.) D.Mohr, Hypnum cupressiforme Hedw., Leucobryum glaucum (Hedw.) Ångstr., Polytrichum formosum Hedw. and Scapania nemorea (L.) Grolle. Only a few vascular plants (mainly acidophilous species) were noticed on the poor soil in the acidophytic forests with open canopy, e.g. Deschampsia flexuosa (L.) Trin., Fagus sylvatica L., Genista pilosa L., Gentiana asclepiadea L., Hieracium sabaudum L., Luzula luzuloides (Lam.) Dandy \& Wilmott, Lychnis viscaria L., Quercus petraea (Matt.) Liebl. agg. and Vaccinium myrtillus L. Contrary to the usual domination by limestones in Croatia, Papuk Mt exhibits a variety of acidic eruptive and metamorphic rocks, thus being a suitable habitat for acidophilous mosses and liverworts. Several species new for the Croatian bryoflora were recently recorded here: Microlejeunea ulicina (Taylor)
A.Evans, Rhabdoweisia fugax (Hedw.) Bruch \& Schimp., Sciuro-hypnum flotowianum (Sendt.) Ignatov \& Huttunen, Syntrichia calcicola J.J.Amann and Tortella bambergeri (Schimp.) Broth. (Papp et al., 2013; Alegro et al., 2014). Furthermore, based on recent collections, Dicranum spurium Hedw. found at Svinjarevac (Ellis et al., 2014c) and Andreaea rothii F.Weber \& D.Mohr subsp. rothii found at Sokolina (Ellis et al., 2016c) were added to the checklist of Croatia as well.

8. Buxbaumia viridis (Moug. ex DC.) Brid. ex Moug. $\&$ Nestl.

Contributors: Í. Granzow-de la Cerda and L. Sáez

Andorra: Ordino, Bosc del Coll d'Ordino, 42 $33^{\prime} 17^{\prime \prime} \mathrm{N}, 1^{\circ} 33^{\prime} 21^{\prime \prime} \mathrm{E}$ (UTM 31T 03814 47123), 1750 $\mathrm{m}$ a.s.l., on decaying $\log$ in Abies alba forest, 7 November 2015, leg. Í. Granzow 7381 \& L. Sáez (BCB 58723).

Buxbaumia viridis is a moss that grows almost exclusively on dead softwood and decaying logs and stumps in coniferous forests. It is sparsely distributed in the northern hemisphere, in the mountains of westcentral Asia, Europe and western North America. Buxbaumia viridis is locally rather common in Scandinavia, but rare elsewhere in Europe (Hallingbäck, 2002; Spitale \& Mair, 2017).

According to Casas (2005) and Ros et al. (2013) this species had not been recorded from Andorra, although it is known from neighbouring areas in the central and eastern Pyrenees (Casas et al., 2003), where it usually grows in subalpine Abies alba Mill. forests on the northern and southern slopes.

This record, the first for Andorra, confirms that the species is more common in the Pyrenees than the regional literature may suggest.

9. Campylium longicuspis (Lindb. \& Arnell) Hedenäs

Contributors: V. E. Fedosov and L. N. Beldiman

Russia: Novaya Zemlya Archipelago, northern shore of Northern Island between Elisabeth Cape and Loshkina Cape, $76^{\circ} 57.358^{\prime} \mathrm{N}, 68^{\circ} 06.235^{\prime} \mathrm{E}, c a$ $50 \mathrm{~m}$ a.s.1., in Cerastium regelii Ostenf. and moss dominated community, on moist soil with Orthothecium chryseon (Schwägr.) Schimp., Distichium capillaceum (Hedw.) Bruch \& Schimp., Pseudocalliergon brevifolium (Lindb.) Hedenäs, etc., 01 August 2016, leg. L. N. Beldiman s.n. (MW); north-western shore of Northern Island near Russian Harbour field station, $76^{\circ} 11.766^{\prime} \mathrm{N}, 62^{\circ}$ $35.194^{\prime} \mathrm{E}$, ca $30 \mathrm{~m}$ a.s.1., gentle gravelly slope with scattered Saxifraga oppositifolia L., S. cespitosa L. and mosses, 16 June 2016, leg. L. N. Beldiman s.n. (MW).

The species has been described from the lower courses of the Ynisey and Lena Rivers in subarctic Siberia, and has a mostly Arctic and subarctic distribution, from Greenland to the Chukotka Peninsula. 
Hedenäs (1989) considered it as circumpolar, and indeed, Afonina (2004) mentioned one locality in the Canadian Arctic Archipelago, which was omitted from the "Flora of North America" (Hedenäs, 2014). The species is known to avoid the High Arctic and hitherto, the only known locality in the polar deserts of the northern hemisphere was in North East Land of Svalbard (Frisvoll \& Elvebakk, 1996). Thus the species is newly discovered for the insular part of the Russian Arctic, while the first locality, considered herein is the second occurrence of the species in the polar deserts of the northern hemisphere. These records seem to be quite predictable, since (1) Novaya Zemlya has extensive outcrops of calcareous bedrocks, (2) the polar deserts descend to the lowest latitudes worldwide in this archipelago and (3) the bryophyte flora here is still insufficiently studied.

10. Cratoneuron filicinum (Hedw.) Spruce

Contributors: K. K. Rawat, V. Sahu and A. K. Asthana

India: Arunachal Pradesh, Tawang, on way to Tawang monastery, $27^{\circ} 35^{\prime} 49.8^{\prime \prime} \mathrm{N}, 91^{\circ} 51^{\prime} 53.7^{\prime \prime} \mathrm{E}$, ca $2999 \mathrm{~m}$ a.s.1., on soil, 16 June 2016, leg. K. K. Rawat s.n. (LWG 300237D).

The occurrence of Cratoneuron (Sull.) Spruce in India has been recorded by Gangulee (1978), Chopra (1975), Vohra (1983) and Lal (2005). The present report of $C$. filicinum, earlier recorded from Jammu, Kashmir and Uttarakhand (Garhwal and Kumaon), constitutes the first record of the genus, as well as this species, from the Eastern Himalayas, India.

The plants were pinnately to irregularly branched, with brown tomentum and lanceolate paraphyllia on the main stem. Stem leaves were ovate-lanceolate to ovate-cordate, acuminate, with a slightly dentate margin at the apex. A stout costa ended just below the leaf apex. Similarly costate, the branch leaves were small, lanceolate with an acute apex. Alar cells at the leaf base were in 3-4 rows, thin-walled, 40 $80 \times 16-20 \mu \mathrm{m}$. The specimen lacked sporophytes.

11. Dactylophorella muricata (Gottsche) R.M.Schust.

Contributors: K.-T. Yong and M. S. Chan

Peninsular Malaysia: Perak, Kinta Valley, Gunung Rapat (Hill), one of the limestone hills between Simpang Pulai and Ipoh Town, 280-320 m a.s.1., on root mesh and epiphyllous, 7 October 2016, leg. K.-T. Yong, S. H. Ong \& M. S. Chan 9604, 9605, 9606, 9607, 9608 (KLU).

This curious looking leafy liverwort is a member of the Lejeuneaceae. The species is highly distinctive with its concave lateral leaf lobe with a margin further dividing into 5-7 slender lobes, and all armed with long spinose teeth. These teeth are in two rows, pointing in different directions, or almost perpendicular to each other. The underleaves are small, one per pair of lateral lobes, divided and the margins are usually spinose-dentate just as in the lateral leaves. Margins of the underleaves with broad teeth were also common in the specimen examined. Nevertheless, after a detailed search of the entire collection, there were found some branches bearing underleaves with spinose margins. This species has thus far only been reported from Borneo, Java, the Philippines, Sumatra and Sulawesi, from both limestones and non-karst habitats (Herzog, 1934; Mizutani, 1970; Söderström et al., 2010). It was found epiphytic on trunks and branches, or as epiphylls (Mizutani, 1970). Due to its small size, this species can also be found growing on other bryophytes, for instance in the present study, it was epiphytic on Fissidens oblongifolius Mont.

12. Delongia glacialis (C.C.Towns.) N.E.Bell, Kariyawasam, Hedd. \& Hyvönen

Contributors: V. Sahu, A. K. Asthana and K. K. Rawat

India: Uttarakhand, Uttarkshai, Govind Wildlife Sanctuary, Near Devbasa, 3734 m a.s.1., on soil, 9 October 2015, leg. K. K. Rawat s.n. (LWG 300504D).

Townsend (1998) reported a new species, Oligotrichum glaciale C.C.Towns. [三 Delongia glacialis (C.C.Towns.) N.E.Bell] from Kashmir (at the edge of melting snow below crags above the stream, Rasbal). Here, the species is reported for the first time in India from Uttarakhand.

The plants were brown to yellowish-brown, small, erect and unbranched, 6-12 $\mathrm{mm}$ high, with leaves curled and appressed to stem when dry. The leaves were deeply concave, closely imbricate, ovate-lanceolate, 2-3 mm long and 1-1.2 $\mathrm{mm}$ wide with an acute, dentate apex. Leaves in cross-section showed ventral lamellae 4-8 cells high, dorsal lamellae were absent. Sporophytes were absent.

13. Dicranum leiodontium Cardot

Contributors: Y.-J. Yoon, S. J. Park and B.-Y. Sun

Republic of Korea: Gangwon-do, Hongcheon-gun, Nar-myeon, Bangrae-ri, $37^{\circ} 48^{\prime} 16.3^{\prime \prime} \mathrm{N}, 128^{\circ} 16^{\prime} 08.1^{\prime \prime} \mathrm{E}$, $542 \mathrm{~m}$ a.s.l.; on rock on partially shaded talus slope, 23 September 2015, leg. S.-J. Park 13267 (JNU).

This species of Dicranum Hedw. was long considered a Japanese endemic (Noguchi, 1987) until the report of its presence in China published in Gao et al. (1999). It is distinguished by a combination of characters, including small plant size of about $1-2.5 \mathrm{~cm}$ tall, a mixture of quadrate and rectangular cells in the upper leaf lamina, leaf margins and abaxial side of costa weakly serrate, a long setaceous excurrent costa and an erect, obloid to cylindrical capsule. Good illustrations of this species can be found in Takaki (1964), Noguchi (1987) and Gao et al. (1999).

Plants of Dicranum leiodontium can be confused with those of $D$. hamulosum Mitt. that have similarly 
erect and cylindrical capsules and a long-acuminate leaf apex, but the former species has a setaceous, excurrent leaf costa, while the latter has only a percurrent costa (Noguchi, 1987).

Sterile plants of $D$. leiodontium may be mistaken also for Dicranum klautkei Reimers, a Korean endemic identified by its somewhat curved capsule. Dicranum klautkei is known, to date, only from the type specimen collected from Kumgangsan in Onjöng-ni at Yujomsa (coll. P. Klautke 241). However, the binomial of Dicranum klautkei is misspelled as 'D. klauteri' in the TROPICOS moss database housed at MO Herbarium and also in the latest national checklist of mosses in Korea (Ahn et al., 2011).

As a species record, Dicranum leiodontium is not included in the lists of the Korean bryoflora prepared by Park \& Choi (2007) and Ahn et al. (2011). Gao et al. (1999) mentioned 'China, Korea and Japan' in passing for the distribution of this species. Our collection represents the first confirmed record of this species in Korean Peninsula.

\section{Grimmia dissimulata E.Maier}

Contributor: N. G. Hodgetts

Portugal, Madeira: Pico do Arieiro, volcanic rocks on summit ridge, $32^{\circ} 44^{\prime} 08^{\prime \prime} \mathrm{N}, 16^{\circ} 55^{\prime} 44^{\prime \prime} \mathrm{W}, 1790 \mathrm{~m}$ a.s.1., 16 March 1992, leg. N. G. Hodgetts, 2431 (LISU, MADJ, Herb. Hodgetts), det. R. D. Porley, 17 November 2016.

Since they were collected, these specimens were in my private herbarium as Grimmia trichophylla Grev., but with a question mark. It became clear that they were not that species when the genus Grimmia Hedw. became less opaque owing to further studies, principally by Maier $(2002,2011)$ and Porley $(2004,2016)$, and a useful Grimmia workshop organised by the British Bryological Society, led by Ron Porley, in 2016. They were subsequently redetermined as $G$. dissimulata by Ron Porley. Pico do Arieiro is one of the highest points in Madeira, with extensive outcrops of exposed volcanic rock. Several species of Grimmia have been recorded in Madeira (Sérgio et al., 2006; Hodgetts, 2015), but specimens, especially of G. trichophylla from the high peaks, should probably be reexamined in the light of this record.

15. Grimmia elatior Bruch ex Bals.-Criv. \& De Not

Contributors: V. E. Fedosov and L. N. Beldiman

Russia: Terra Nova (Novaya Zemlya Archipelago), gentle slope on the north-eastern shore of Northern Island between Zhelanija Cape and Iogansena Cape, $76^{\circ} 54.653^{\prime} \mathrm{N}, 68^{\circ} 32.292^{\prime} \mathrm{E}$, ca $40 \mathrm{~m}$ a.s.1., in hollow on high shore, gravelly barren ground with open community of Oxyria digyna (L.) Hill, Cerastium regelii Ostenf., Papaver cf. polare (Tolm.) Perf. and mosses Racomitrium lanuginosum (Hedw.) Brid., Distichium capillaceum (Hedw.) Bruch \& Schimp., Hymenoloma crispulum (Hedw.) Ochyra, Stereodon revolutus Mitt., Schistidium papillosum Culm., Polytrichastrum alpinum (Hedw.) G.L.Sm., Sanionia uncinata (Hedw.) Loeske; 2 August 2016, leg. Beldiman s.n. (MW).

The species has a scattered distribution mainly in boreal and subarctic montane areas of the Holarctic. It is known to be rather frequent in the Byrranga Range (Arctic Taimyr, ca 74th latitude) (Fedosov \& Ignatova, 2005), but until now, had not been found in the insular part of the Russian Arctic. The only part of the Arctic Archipelago where the species has previously been recorded is Svalbard (Frissvol \& Elvebakk, 1996). The present locality provides the second record of the species in the polar deserts of the northern hemisphere ( $c f$. Afonina, 2015).

16. Hedwigia stellata Hedenäs

Contributor: S. Ştefănuţ

Romania: (1) Eastern Carpathians: Rodna Mountains, Pietrosul Borşei, Valea Pietroasă, Maramureş County, 47 $37^{\prime} 28^{\prime \prime} \mathrm{N}, 2^{\circ} 39^{\prime} 27^{\prime \prime} \mathrm{E}, 1000 \mathrm{~m}$ a.s.1., 7 July 1948, leg. T. Ştefureac s.n., det. T. Ştefureac, as Hedwigia albicans Lindb., rev. S. Ştefănuţ (BUCA B5310); (2) Râşca Valley, Cluj County, $46^{\circ} 44^{\prime} 19^{\prime \prime} \mathrm{N}, 23^{\circ} 14^{\prime} 10^{\prime \prime} \mathrm{E}, 600 \mathrm{~m}$ a.s.l., 17 June 1925, leg. G. Bujorean \& E. Pop (Flora Romaniae Exsiccata No 1416a), det. C. Papp, as Hedwigia albicans, rev. S. Ştefănuţ (BUCA B5315).

These are the first records of Hedwigia stellata for Romania (Ştefănuţ \& Goia, 2012). Other historical samples originally determined as Hedwigia albicans (as were those cited above), from the Bucegi Mountains, Gura-Dihamului, leg. P. Cretzoiu (Flora Romaniae Exsiccata No 1416b), det. C. Papp, proved to be Racomitrium elongatum (Ehrh.) ex Frisvoll, rev. S. Ştefănuţ (BUCA B5316-5319).

In Europe $H$. stellata has been reported from Denmark, Finland, Iceland, Norway, Sweden, Channel Islands, Great Britain, Ireland, Northen Ireland, Andorra, Canary Islands, Corsica, Cyprus, France, Italy, Madeira, Portugal, Sardinia, Sicily, Spain, Austria, Belgium, Czech Republic, Germany, Luxembourg, Netherlands, Poland, Switzerland, Bulgaria, Greece, Macedonia, Hungary, Turkey, Estonia (Hodgetts, 2015) and Romania.

17. Herbertus dicranus (Taylor ex Gottsche, Lindenb. \& Nees) Trevis.

Contributors: V. Sahu, A. K. Asthana and K. K. Rawat

India: Western Himalaya: Uttarakhand, Uttarkashi, Govind Wild Life Sanctuary (GWLS), on way to Badang from Bithri, on soil covered trunk base, $31^{\circ}$ $07^{\prime} 27.81^{\prime \prime} \mathrm{N}, \quad 078^{\circ} 6^{\prime} 52.70^{\prime \prime} \mathrm{E}, \quad$ ca $2750 \mathrm{~m}$ a.s.1., 7 October 2015, leg. K. K. Rawat s.n. (LWG 300459C).

The genus Herbertus Gray (Marchantiophyta: Herbertaceae) is represented in India by 10 species (Singh et al., 2016), mostly from the Eastern 
Himalaya and southern India. Its presence in the western Himalayan region of India was only recently reported by Nath et al. (2010), with a record of Herbertus ceylanicus (Steph.) Abeyw. from the Valley of Flowers, Uttarakhand. During our study of bryophytes in GWLS (Uttarakhand), another species of Herbertus, $H$. dicranus has been identified, which is a new addition to the western Himalayas. It was already recorded in India from the eastern Himalayas and southern India. Herbertus dicranus is an extremely variable species. The plants in our collection can be described as follows.

Plants brownish; stems producing frequent flagelliform branches; leaves transversely inserted, asymmetrical, falcate, 1.2 to $1.6 \mathrm{~mm}$ long, $0.40-0.66 \mathrm{~mm}$ wide, length-width ratio $2.5-3.0$, bifid lobes usually acute, 2-4 uniseriate cells present at apex, margin entire; leaf apical cells $8-12 \mu \mathrm{m}$ long, $8-12 \mu \mathrm{m}$ wide, short quadrate, thick-walled; basal cells $12-16 \mu \mathrm{m}$ long, $12-16 \mu \mathrm{m}$ wide, polygonal, trigonous, thickwalled, dorsal lamina base 10-20 cells wide; vitta conspicuous, extending to $1 / 2$ to $1 / 3$ of lobe, vitta cells 38-48 $\mu \mathrm{m}$ long, $12-16 \mu \mathrm{m}$ wide, in mid basal lamina 20-30 cells between sinus and vitta bifurcation point; underleaves more or less similar to leaves.

18. Lescuraea plicata (Schleich. ex F.Weber \& D.Mohr) Broth.

Contributors: M. J. Cano and J. Guerra

Andorra: Ski resort of Arinsal, $42^{\circ} 34^{\prime} \mathrm{N}, 01^{\circ} 27^{\prime} \mathrm{E}$, $2235 \mathrm{~m}$ a.s.l., on calcareous rock crevice, 15 July 2015, leg. M. J. Cano 9084 (MUB 50262).

Lescuraea plicata (= Ptychodium plicatum (Schleich. ex F. Weber \& D.Mohr) Schimp.) is an Arctic-alpine species, occurring widely in Europe from the far north to the mountains of the south and from the Caucasus (Hill et al., 1994) to the Iberian Peninsula where it has a narrow distribution range, occurring in high mountains including the Pyrenees (Lleida, Huesca provinces) and the Cantabrian Mountains (Palencia province) (Casas et al., 2006; Brugués \& Ruiz, 2016). The species is easily recognised by its robust size, abundant paraphyllia on the stem, ovate-lanceolate, abruptly acuminate and strongly longitudinally plicate leaves, smooth and elongate laminal cells and costa that ends near the leaf apex (Smith, 2004; Casas et al., 2006).

As a result of intensive field trips in connection with the 'Flora Briofítica Ibérica' project, new species have been added to the moss flora of Andorra in recent years (Brugués, 2007; Ellis et al., 2014b, 2016a). Herein, the range of Lescuraea plicata is extended to this country. The specimen was found growing in a crevice in calcareous rock on accumulated soil at $2235 \mathrm{~m}$ elevation. This habitat is similar to others reported for this taxon in Europe.

19. Marchantia paleacea Bertol.
Contributors: S. Poponessi, M. Aleffi and R. Venanzoni

Italy: Umbria Region, Province of Terni, 'Parco Fluviale del Nera' Regional Park, Marmore Waterfall, 'Petrifying springs with tufa formation (Cratoneurion)', $42^{\circ} 33.230^{\prime} \mathrm{N}, 12^{\circ} 42.733^{\prime} \mathrm{E}$, ca $218 \mathrm{~m}$ a.s.l., wet slope, 24 March 2016, leg./det. S. Poponessi s.n. (PERU).

This record is in a Site of Community Importance (SCI) IT5220017 and a Special Area of Conservation (SAC) of the Natura 2000 EU-wide network due to the presence of the $72.20^{*}$ 'Petrifying springs with tufa formation (Cratoneurion)' Annexe I priority habitat (http://vnr.unipg.it/habitat/). The particular environment, with a gorge and waterfall, created a very special microclimate that allowed the establishment of interesting liverworts and mosses (Poponessi et al., 2014; Ellis et al., 2014b, 2016c).

Marchantia paleacea is a new species for the Umbria Region and is rare in central and southern Italy. Recent records include only Tuscany, Lazio, Abruzzo, Campania and Sicily (Aleffi et al., 2008), while older records include Apulia and Calabria (Rabenhorst, 1848; Arcangeli, 1889).

This taxon has been assigned to the tropical montane-submeridional geographical element (Dierßen, 2001). According to Hodgetts (2015) it is considered as Near Threatened (NT) for Italy; Endangered (EN) for the Canary Islands and Vulnerable (VU) for Serbia. Its Mediterranean range includes Albania, Algeria, Baleares, Canary Islands, Corsica, Croatia, Greece, Italy, Montenegro, Spain, Sicily and Turkey (Ros et al., 2007).

Marchantia paleacea is easily distinguishable from M. polymorpha s. $l:$ the ventral scales are in two rows on each side of the midrib, and are small, elliptical and caduceus and the inner epidermal pores are narrowly cross-shaped (Bischler-Causse, 1989). Plants are usually without sporophytes but possess gemmae-cups. In its newly discovered locality, $M$. paleacea formed abundant green patches with purplish margins, on calcareous rocks.

20. Moerckia flotoviana (Nees) Schiffn.

Contributors: M. Infante and P. Heras

Spain: Asturias, Morcín, Cantu la Ripia-Fuente Blanca, near La Carbayosa. $43.25237^{\circ} \mathrm{N}, 5.93060^{\circ} \mathrm{W}$, $539 \mathrm{~m}$ a.s.1., on north-facing travertine walls, 24 August 2016, leg. P. Heras \& M. Infante, VIT 38695 $(603 / 16)$.

This is the first record of Moerckia flotoviana both in Spain and the Cantabrian range, the nearest populations being in the Pyrenees (France) (Infante Sánchez, 2015). The site is located to the north and below the limestones of Sierra del Aramo. Both male and female plants were present, these last bearing perianths. Accompanying species on the 
travertine building were Adiantum capillus-veneris L., Pinguicula grandiflora Lam., Molinia caerulea (L.) Moench, Erica vagans L. and the bryophytes Southbya tophacea (Spruce) Spruce, Preissia quadrata (Scop.) Nees, Aneura pinguis (L.) Dumort., Jungermannia atrovirens Dumort., Pellia endiviifolia (Dicks.) Dumort. and Eucladium verticillatum (With.) Bruch \& Schimp.

21. Plagiothecium latebricola Schimp.

Contributors: K. Baráth and P. Erzberger

Hungary: Vas County, Köszeg Mts [8664.2] (Central European Mapping Scheme), ca $5 \mathrm{~km}$ west of the town of Köszeg, ca 10-30 m from the border with Austria, in alder carr along the stream Hármas-patak below Stájer-házak, at the base of Alnus glutinosa (L.) Gaertn. trees, on bark and partly decayed wood, particularly in recesses between roots, $c a 360 \mathrm{~m}$ a.s.1., $47^{\circ}$ $23^{\prime} 12.3^{\prime \prime} \mathrm{N}, 16^{\circ} 27^{\prime} 21.3^{\prime \prime} \mathrm{E}, 14$ October 2016, leg. P. Erzberger \& K. Baráth s.n. (B-Erzberger 22303, 22304, hb. Baráth, dupl. hb. Németh, BP); earlier collected from near this site on 15 July 2016, leg. K. Baráth s.n., det. P. Erzberger, 22 July 2016, conf. L. Meinunger \& W. Schröder, 16 August 2016 (B-Erzberger s.n.).

Plagiothecium latebricola is a slender plant that can easily be overlooked or mistaken for a diminutive Hypnum Hedw. or another species of Plagiothecium Schimp. Having laminal cells less than $10 \mu \mathrm{m}$ wide, it is most closely related to P. laetum Schimp. and $P$. curvifolium Schlieph. ex Limpr., two species that also share with $P$. latebricola the \pm narrow-celled decurrencies remaining on the stem when leaves are removed. However, P. latebricola has symmetrical leaves that are more gradually narrowed to a long-acuminate apex and in particular, nearly always display some fusiform gemmae at the leaf tip.

Plagiothecium latebricola usually grows on decaying vegetable matter such as fern stools and Carex tussocks in moist and shaded places, in particular in alder carr at the base of living trees, but mostly on locally decaying bark or wood. It is generally a lowland plant, but rarely also occurs on acidic rock in hilly areas. The occurrence reported here is quite typical in this respect.

Among the countries surrounding Hungary, the species occurs in Austria, Serbia, Romania, the Ukraine and Slovakia. It is Red-Listed in Austria (2), Romania (CR) and Slovakia (CR) (Hodgetts, 2015). Since the appropriate habitat is present in Hungary, the occurrence of P. latebricola was to be expected, and it can probably be found elsewhere in the country, at least in areas with lime-free ground. Since it is very inconspicuous it has most likely been overlooked, and is missing from the latest checklist of Hungarian bryophytes (Papp et al., 2010).
Plagiothecium latebricola is widespread in Europe except in the south, and also occurs in Turkey, Georgia, Kyrgyzstan, Siberia to East Asia, Japan, and in eastern North America (Hodgetts \& Blockeel, 2014; Hodgetts, 2015).

22. Pohlia lutescens (Limpr.) H.Lindb.

Contributors: T. Ezer, G. Uyar, M. Ören and M. Alataş

Turkey: Kocaeli Province, Samanlı Mountains, Kartepe district: $40^{\circ} 40^{\prime} 37.8^{\prime \prime} \mathrm{N}, \quad 30^{\circ} 03^{\prime} 46.3^{\prime \prime} \mathrm{E}$, growing on wet soil, under Castanea sativa Mill. forest, $427 \mathrm{~m}$ a.s.1., 05 September 2015, leg. and det. T. Ezer, G. Uyar \& M. Ören s.n. (GAZI BRY 1502).

During examination of samples collected from the Samanl1 Mountains in the northwest of Turkey, small and delicate plants were identified as Pohlia lutescens (Limpr.) H.Lindb., a species not previously reported from Turkey. The genus Pohlia Hedw. in the family Mielichhoferiaceae, is represented in Turkey by 17 taxa (Uyar \& Çetin, 2004; Kürschner \& Erdağ, 2005; Kürschner \& Frey, 2011; Ros et al., 2013; Uyar \& Ören, 2013). This new record, P. lutescens, brings the total to 18 (14 species and 4 varieties).

Pohlia lutescens is a small, delicate species, easily recognised by the pale yellow or occasionally light reddish-brown, rounded to ovoid, knobbly rhizoidal tubers and narrow lanceolate leaves with narrow laminal cells (Bezgodov \& Ignatova, 2013). Pohlia lutescens was considered to be endemic to Europe, extending northwards from Italy to Scandinavia. It is rather common in England, Wales and Ireland, but rare in Scotland (Smith, 2004; Bezgodov \& Ignatova, 2013), and has been recorded from Sweden and Denmark, Poland, Bulgaria, France, Serbia and Slovenia (Ochyra et al., 2003; Bezgodov \& Ignatova, 2013; Ros et al., 2013). Pohlia lutescens has also been widely reported on bare soils from Asia (China, Mongolia, Russia and Japan) (Bezgodov \& Ignatova, 2013). The present record from Turkey is an important extension of its range southwards towards the Middle East. This study is based on herbarium material (GAZI BRY) collected from northwestern Anatolia (Samanlı Mountains, Kocaeli Province) on 5 September 2015. The specimen occurred on wet soil, growing in association with Dicranella heteromalla (Hedw.) Schimp. The plants were sterile, and therefore, sporophytes are unknown in Turkey.

Pohlia lutescens is easily distinguished from other tuber-bearing species of Pohlia by its knobbly, pale yellow to orange or pale brownish rhizoidal gemmae. It differs from $P$. lescuriana (Sull.) Ochi by its slightly narrower laminal cells, sharply differentiated perichaetial leaves and, sharply denticulate upper leaves. Also, the rhizoidal gemmae in P. lescuriana and $P$. melanodon (Brid.) A.J.Shaw are smooth 
rather than knobbly (Smith, 2004; Bezgodov \& Ignatova, 2013).

23. Pseudocrossidium obtusulum (Lindb.) H.A.Crum \& L.E.Anderson

Contributor: I. V. Czernyadjeva

Russia: Southern Siberia, Republic of Buryatia, Baikal Lake, Chivyrkuisky Gulf, Malyi Koltygei Island, 534ㅇ $46^{\prime} 41.9^{\prime \prime} \mathrm{N}, 109^{\circ} 05^{\prime} 30.7^{\prime \prime} \mathrm{E}, 477 \mathrm{~m}$ a.s.1., in niches of rocky outcrops near to the bird bazaar, 1 July 2014, leg. I. V. Czernyadjeva \# 27-14 (LE).

Pseudocrossidium obtusulum is known from a few localities in Europe, North America and Asia (Fedosov \& Ignatova, 2006; Zander, 2007). This is the first report of $P$. obtusulum from the Republic of Buryatia. The closest other known localities for the species are in Siberia in the Republic of Altai (Pisarenko, 2007). It is very rare in Russia, recorded from a few localities in the European part: Rostovna-Donu Province, Perm Province; Caucasus: Republic of Kabardino-Balkaria; Siberia: Taimyr Autonomous District, Republic of Sakha/Yakutia (Fedosov \& Ignatova, 2006; Doroshina, 2012).

This species was described and illustrated in a revision of Pseudocrossidium R.S.Williams in Russia by Fedosov \& Ignatova (2006). They noted that gemmae are not always present, especially in collections from Asian Russia. Moreover, all specimens from Russia are sterile. The specimen from Buryatia does not possess gemmae, but has several capsules. Pseudocrossidium obtusulum prefers to grow in xeric habitats: steppe slopes, on limestone, shell-rock, calcareous outcrops.

24. Pseudotaxiphyllum distichaceum (Mitt.) Z.Iwats.

Contributors: R. Ochyra and M. J. Wigginton

St Helena Island: Diana's Peak National Park: (1) Actaeon Peak, Cuckold 01, UTM grid ref. 30L/TH/ $101328,785 \mathrm{~m}$ a.s.1., $15^{\circ} 58^{\prime} \mathrm{S}, 5^{\circ} 42^{\prime} \mathrm{W}$, on steep Wfacing slope, on soil in deeply shaded crevice under a tree-fern, Dicksonia arborescens L'Hér., 31 October 2005, leg. M. J. Wigginton 05/346, det. R. Ochyra (E 00776310); (2) same locality, on soil and rotting vegetation in hollow beneath tree-fern, 31 October 2005, leg. M. J. Wigginton 05/334, det. R. Ochyra (E 00775308); (3) Cuckold's Peak, Actaeon 01, UTM grid ref. 30L/TH/105324, $809 \mathrm{~m}$ a.s.1., $15^{\circ}$ $58^{\prime} \mathrm{S}, 5^{\circ} 42^{\prime} \mathrm{W}$, on vertical surfaces of rock and peaty humus, in deep crevice, in shade under Norfolk Island Pine, summit of Mt Cuckold, with Kurzia nemoides (Hook.f. \& Taylor) Grolle, 25 October 2005, leg. M. J. Wigginton 05/212 B, det. R. Ochyra (E 00775311); (4) Dianas 03, UTM grid ref. 30L/ $\mathrm{TH} / 105327,746 \mathrm{~m}$ a.s.1., $15^{\circ} 58^{\prime} \mathrm{S}, 5^{\circ} 42^{\prime} \mathrm{W}$, on moist peaty soil with decaying plant remains, under rock overhang, with a tree-fern canopy, with Fissidens chioneurus Müll.Hal. and Kurzia nemoides 22 October 2005, leg. M. J. Wigginton 05/146C, det. R. Ochyra
(E 00775324); (5) same locality, on very wet peat on shaded vertical rock scar, deeply shaded by treeferns, 22 October 2005, leg. M. J. Wigginton 05/ 148A, det. R. Ochyra (E 00775323).

St Helena is one of the most remote islands in the world. It is located in the South Atlantic Ocean, $3300 \mathrm{~km}$ from Brazil and about $1900 \mathrm{~km}$ from Angola, and is of relatively recent volcanic origin, emerging from the Mid-Atlantic Ridge some 12-14 million years ago. Its flora was established via the aerial dispersal of propagules from Africa, the Americas and elsewhere, some of which subsequently evolved into new endemic species. As is the case with all oceanic islands of volcanic origin, the moss flora of St Helena is relatively poor, and is still underworked. At the beginning of the last century only 32 species of moss had been reported from the island (Geheeb, 1910), but as a result of a major survey of the island's bryoflora, the total currently consists of 68 species, including about eight species determined only to genus (Wigginton, 2012). One of these unnamed species has now been identified as Pseudotaxiphyllum distichaceum. The species is apparently scarce and is currently known from only a single $1 \times 1 \mathrm{~km}^{2}$, in cloud forest at high elevations along the Central Ridge area of the Island. The St Helena plants perfectly match the American material of the species. They have squarrose, complanate, asymmetric and often cultriform leaves that are gradually acuminate, serrulate at magins and have poorly differentiated alar cells. Additionally, they occasionally produce in the upper leaf axils the twisted-vermiform brood-bodies with several (1-5) acute teeth at their apex that are the most characteristic feature of the species.

Pseudotaxiphyllum distichaceum is an eastern North American temperate species, deeply penetrating into the tropics, mostly at high elevations in the American Cordillera. Its geographical range covers eastern North America north of Mexico (Ireland, 2014) and then the species recurs at widely scattered locations in Latin America, ranging from Mexico through the Central American isthmus and the West Indies to the northern Andes in South America, with a highly isolated station in SE Brazil (see distribution map in Ireland \& Buck, 2009). The species was reported from Hainan island in China (Redfearn et al., 1996) but this record has not been confirmed (Zhang \& He, 2005). Likewise, although Australia has sometimes been included in the distribution of P. distichaceum (e.g. Arts, 2005; Ireland \& Buck, 2009), it is not accepted in the Australian checklist (Streimann \& Klanzenga, 2002) or in the online flora (Ramsay et al., 2012).

The phytogeographical status of $P$. distichaceum has been changed after its discovery at a number of montane stations on Réunion in the Mascarene 
Islands, an East African Indian Ocean island (Arts, 2005). Accordingly, it must be now considered an Afro-American oreophyte having the main centre of its distribution in the Americas. Its presence on the West African island of Saint Helena confirms this status. It has not yet been reported from mainland Africa, but in view of the large number of species of Isopterygium Mitt. described from continental Africa, most of which have not been studied taxonomically, it is possible that some may prove to belong to P. distichaceum, thereby demonstrating a wider African range. An amphiatlantic (Afro-American) distribution is being demonstrated for an increasingly large number of species, currently for 78 species of hepatics (Gradstein, 2013; Ellis et al., 2013a, 2013b, 2013c, 2014b) and for well over 80 species of moss. Apart from a large group of tropical lowland and montane species (e.g. Frahm, 1982; Ochyra et al., 1992; Bednarek-Ochyra et al., 1999; Ellis et al., 2012a, 2012b), a relatively small group of south-temperate cool-adapted moss species also show this type of distribution (e.g. Ochyra \& Lewis Smith, 1998; Ochyra et al., 2002, 2008, Ochyra, 2010; Bednarek-Ochyra \& Ochyra, 2013; Ochyra et al., 2014).

25. Radula fauriana Steph.

Contributors: V. A. Bakalin and K. G. Klimova

Russian Federation (the Russian Far East): Sakhalin Province, Sakhalin Island, Dolinskiy District, Anna River Valley in the area adjacent to its mouth, $47^{\circ}$ $09^{\prime} 45.7^{\prime \prime} \mathrm{N}, 143^{\circ} 01^{\prime} 43.9^{\prime \prime} \mathrm{E}, 10 \mathrm{~m}$ a.s.l., moist open cliff near sea coast, 29 September 2016, leg. V. A. Bakalin \& K. G. Klimova s.n. (VBGI: S-4530-16).

This species has a characteric suboceanic to oceanic oro-boreal East Asian distribution and is fairly common in Hokkaido and Honshu (Yamada \& Iwatsuki, 2006). Aside from Japan there is a record of Radula fauriana from the northern part of the Korean Peninsula (Kim \& Hwang, 1991). The distribution of the species in Sakhalin Island, at the southern tip of the Russian Far East was therefore quite expected. The ecology of the species in Sakhalin is different from that in Japan (Yamada, 1979), where $R$. fauriana occurs on the bark of trees rather than on coastal cliffs. However we are inclined to regard this discrepancy as the result of adaptation to the more severe climatic conditions in Sakhalin.

\section{Riccia glauca L.}

Contributors: A. Martins, M. Sim-Sim, C. A. Garcia, F. Reis and S. Fontinha

Madeira: Fajã da Ovelha, access trail to Ladeira dos Zimbreiros (trail between Fajã da Ovelha and Ribeira da Galinhas in Paúl do Mar), next to the parking lot in ER 223 Road Fajã da Ovelha, 390 m a.s.l., 32.770966 $\mathrm{N}, 17.234797^{\circ} \mathrm{W}$, on wet soil, 16 November 2016, leg. A. Martins, M. Sim-Sim, \& F. Reis, s.n. (LISU).
On a recent field trip to the island of Madeira we collected Riccia glauca, thus confirming its presence on the island. It was first reported as Riccia glauca fo. ciliata L. and Riccia glauca var. commutata Jack ex Levier by Armitage (1910), in two localities on the island, near the city of Funchal, but according to Sérgio et al. (2006) no herbarium material of these collections has been found. (Riccia glauca var. commutata is now a synonym of Riccia warnstorfii Limpr. ex Warnst.)

The newly discovered plants of Riccia glauca formed rosettes with lobes $3 \mathrm{~mm}$ wide possessing margins without cilia, and with spores $c a 80 \mu \mathrm{m}$ in diameter. They occurred on wet soil at the margins of a trail on the south-western slope of Madeira Island, facing the sea, associated with Mannia androgyna (L.) A.Evans. Riccia glauca, a typically ephemeral species, occurs on disturbed, acid soil (most characteristically on base-poor clays and sands) in stubble fields, and colonies are usually associated with a diverse range of bryophytes (Preston et al., 2010).

Riccia glauca is a circumpolar southern-temperate species, widespread in Europe from southern Scandinavia southwards, Macaronesia, North Africa, southern west Asia, China, Korea, Japan and North America from Alaska to Texas (Preston \& Bosanquet, 2014). In Macaronesia this species is known from the Azores (Terceira, Santa Maria and São Miguel Islands), Canary Islands (Gran Canaria, La Gomera, La Palma and Tenerife), Madeira and Porto Santo (Costa \& Persson, 1941; GonzálezMancebo et al., 2008; Gabriel et al., 2011).

27. Ricciocarpos natans (L.) Corda

Contributors: V. Šegota, A. Alegro, S. Ozimec, N. Vuković, N. Koletić, D. Prlić and M. Bontek

Croatia: oxbow of the Drava river, in the village of Struga, $46^{\circ} 18^{\prime} 16^{\prime \prime} \mathrm{N}, 16^{\circ} 38^{\prime \prime} 48^{\prime \prime} \mathrm{E}, 25$ June 2006, leg. M. Bontek s.n., det. J. Topić (ZA); Podunavlje

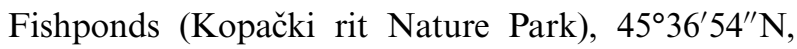
$18^{\circ} 47^{\prime \prime} 53^{\prime \prime}$ E, 02 July 2010, leg. \& det. S. Ozimec s.n. (ZA); Mali Sakadaš backwaters, near Kopačevo Visitor Centre (Kopački rit Nature park), $45^{\circ}$ $36^{\prime} 28^{\prime \prime} \mathrm{N}, 18^{\circ} 47^{\prime \prime} 27^{\prime \prime} \mathrm{E}, 02$ July 2010, leg. \& det. S. Ozimec s.n. (ZA); Novi Senkovac near town of Slatina, locality Suhi rit, western lake, $45^{\circ} 45^{\prime} 16^{\prime \prime} \mathrm{N}$ $17^{\circ} 46^{\prime} 0^{\prime \prime} \mathrm{E}, 19$ April 2014, leg. \& det. Dragan Prlić s.n. (ZA); Sakadaš lake (Kopački rit Nature park), $45^{\circ} 36^{\prime} 42^{\prime \prime} \mathrm{N}, 18^{\circ} 48^{\prime \prime} 01^{\prime \prime} \mathrm{E}, 20$ June 2015, leg. \& det. A. Alegro s.n. (ZA); Rakovica stream, between villages of Donji Vidovec and Kotoriba, $46^{\circ} 20^{\prime} 19^{\prime \prime} \mathrm{N}$, $16^{\circ} 48^{\prime \prime} 32^{\prime \prime} \mathrm{E}, 17$ July 2016, leg. N. Vuković \& N. Koletić s.n., det. V. Šegota \& A. Alegro (ZA).

Ricciocarpos natans is reported from several localities. It was discovered during extensive surveys of the macrophytic vegetation throughout Croatia. It has not been recorded in Croatia before and therefore, 
is not listed in any checklist (Pavletić, 1955; Sabovljević, 2003; Sabovljević \& Natcheva, 2006). In Balkan countries it is known from Bulgaria, Bosnia and Herzegovina, Greece, Macedonia, Montenegro, Romania and Serbia (Sabovljević \& Natcheva, 2006; Hodgetts, 2015). Additionally, the species is known from neighbouring Slovenia and Hungary. It is treated as Critically Endangered (CR) in Slovenia, Endangered (EN) in Austria and Spain, Vulnerable (VU) in Slovakia and Switzerland and Near Threatened (NT) in Italy, Ireland, Czech Republic and Hungary (Hodgetts, 2015).

Based on our recent findings, the species occurs in northern and eastern Croatia, mostly in backwaters, or areas subject to inundation, of the large rivers Danube, Drava and Mura. Mainly floating forms were found in all six localities.

In northern Croatia, the Drava River has been intensively used for hydropower plants, and several reservoirs were constructed. However, some backwaters and oxbows remained. In one oxbow (old river bed) near the Donja Dubrava reservoir, in the village of Struga, $R$. natans was found growing in large quantity forming large carpets on the water surface. The liverwort was recorded within the floating vegetation of Lemnetum trisulcae Knapp et Slofférs 1962. Similarly, the species was found in a small body of stagnant water, which was part of the drainage system of flooded fields, within the inundation area of the Drava River near the village of Novi Senkovac (town of Slatina). Floating forms were found near the banks, and terrestrial forms on the moist remnants of the water vegetation in places where the water had retreated, covering altogether around $2 \mathrm{~m}^{2}$. Both forms were found on the site, co-existing with Riccia fluitans L. The third locality, Rakovica stream, was an originally natural, but artificially deepened, slowflowing lowland stream, a tributary of the Mura River, flowing into the Mura just before its confluence with the larger Drava River. Ricciocarpos natans has been found near the banks of the $2 \mathrm{~m}$ broad and $2 \mathrm{~m}$ deep section of the channelled stream near the bridge between villages of Donji Vidovec and Kotoriba. The species occupied not more than $1 \mathrm{~m}^{2}$ of the stream surface, with not more than 50 individuals, 'trapped' among helophytic vegetation, mostly Sparganium erectum L. and Berula erecta (Huds.) Coville. The eutrophication of those three localities was evident, due to the intensive farming (arable crop production and cattle breeding) in the area. Kopački rit Nature Park encompasses a large inundation area of the Danube River in Eastern Croatia. Here, the species was recorded on three relatively close localities: Sakadaš Lake backwaters, Podunavlje fishpond and Mali Sakadaš backwaters, all eutrophic waters with well-developed macrophytic vegetation. Several individuals were found per site, always accompanied by Riccia fluitans.

According to our observations, the species in Croatia occupies relatively small and rather shallow eutrophic stagnant waters in vegetation dominated by minute floating macrophytes e.g. Lemna trisulca L., L. minor L. Spirodela polyrhiza (L.) Schleiden and Salvinia natans (L.) All. and larger floating and submerged species e.g. Nuphar lutea Sibith. \& Sm., Nymphaea alba L., Nymphoides peltata (S.G.Gmel.) Kuntze, Utricularia vulgaris L., Polygonum amphibium L., Ranunculus aquatilis L., Myriophyllum spicatum L. and much rarer associates are Potamogeton crispus L., P. berchtoldii Fieber, Sparganium emersum Rehmann and Hottonia palustris L.

Although hundreds of sections of Croatian rivers, streams and lakes have been studied floristically in the last ten years, the species has been recorded only six times. However, it may not be that rare, since its preferred microhabitats e.g. smaller water bodies with calcareous, mineral-rich, stagnant, slow-flowing or even temporary water (pools, ditches, canals, drains and slow streams) (Frahm \& Frey, 2004; Atherton et al., 2010) are still insufficiently surveyed in Croatia. The species generally indicates eutrophy and is very variable in its occurrence, ranging from dense cover to total absence (Rintanen, 1996).

\section{Schistidium grande Poelt}

\section{Contributor: T. Kiebacher}

Italy: Trentino-Alto Adige, South Tyrol, St. Martin in Thurn, Dolomites, at the summit of the Peitlerkofel, $46^{\circ} 39^{\prime} 31.9^{\prime \prime} \mathrm{N}, 11^{\circ} 49^{\prime} 13.8^{\prime \prime} \mathrm{E}, 2870 \mathrm{~m}$ a.s.l., northfacing slope, on approximately horizontal dolomite rock, 29 December 2015, leg T. Kiebacher 1050 (priv. herb. T. Kiebacher), det. H. Köckinger.

Schistidium grande was described by Poelt (1955) from the Zugspitze, Germany's highest elevation. The species is typically found on calcareous, preferably vertical, rocks on mountain summits in the alpine and subnival zone, where it usually occurs on north-facing sites exposed to the weather (Poelt, 1955; Schlüsslmayr, 2005; Amann et al., 2013). Originating from rock fissures, the species can form extensive cushions up to several centimetres high and more than $10 \mathrm{~cm}$ in diameter (Schlüsslmayr, 2005). In Europe $S$. grande is only known from the Alps, where it has been recorded in Austria (Schlüsslmayr, 2005; Köckinger et al., 2008; Schröck et al., 2013), France (Blom \& De Zuttere, 2002), Germany (Meinunger \& Schröder, 2007) and Switzerland (NISM, 2017).

Schistidium grande is very similar to the alpine morphotype of $S$. brunnescens Limpr. subsp. brunnescens (see Blom, 1996) and the two species can occur together (Schlüsslmayr, 2005). Schistidium grande differs from $S$. brunnescens subsp. brunnescens in that 
it has almost globose capsules (vs. oblong to broadly ovoid) and a short, rudimentary and pale peristome (vs. well developed and orange, orange-brown or orange-red) (Poelt, 1955; Blom, 1996).

Schistidium grande may also be confounded with S. atrofuscum (Schimp.) Limpr. In S. atrofuscum the peristome is likewise rudimentary but it is orange and the capsules are shortly cylindrical or cyathiform (Blom, 1996). Furthermore, in S. atrofuscum the walls of the mid leaf cells are distinctly sinuose, whereas in $S$. grande they are mostly esinuose (Poelt, 1955; Blom, 1996).

This record is not only the first from Italy but also the first in the southern Alps. At the locality cited above, $S$. sordidum I.Hagen was also found. Schistidium sordidum has only recently been reported for the first time from Italy in the region of Veneto (Ellis et al., 2016a) and is herewith also reported from Trentino-Alto Adige.

\section{Ulota macrospora Baur \& Warnst.}

Contributor: J. Kučera

Austria: Styria, Totes Gebirge Mts., Bad Mitterndorf: valley of Salza river, path towards Grundlsee Lake on $\mathrm{N}$ foothill of Mitterwand, $47^{\circ}$ $36^{\prime} 31^{\prime \prime} \mathrm{N}, 13^{\circ} 56^{\prime} 13^{\prime \prime} \mathrm{E}, 1000 \mathrm{~m}$ a.s.l., mixed forest edge at a brook, on bark of Acer pseudoplatanus L., 10 July 2016, leg. J. Kučera 18848 (CBFS), conf. M. Lüth \& F. Lara.

Ulota macrospora was described from two collections from the Black Forest of southern Germany (Baur, 1893). It was later found at several sites in the Swiss Jura (Amann, 1933), but afterwards fell into oblivion, being placed in synonymy with Ulota rehmannii Jur. Subsequently, Boudier \& Pierrot (1996) and Sauer (1998) independently recognised it again as a good species. While the French authors were able to report several recent records from French Burgundy, new records of $U$. macrospora in Germany did not appear until a few years later when Ahrens (2004) reported recent findings from the Black Forest and the Vosges Mountains. Since then, new records have become more frequent, most of them from Germany (Biedermann et al., 2014; Eckstein et al., 2015) but also from neighbouring Luxembourg (Hans, 2004) and the Czech Republic (Biedermann et al., 2014). At its new site in Austria, the patch of several $\mathrm{cm}^{2}$ was misidentified in the field for the rather similar, widely distributed and common U. bruchii Hornsch. ex Brid., therefore the site was not intensively searched to determine the extent of the local population.

30. Weissia controversa Hedw.

Contributors: K.-T. Yong and M. S. Chan

Peninsular Malaysia: Pahang, Cameron Highlands, a vegetable farm near to Tringkap town, $1300 \mathrm{~m}$ a.s.1., on cut slope of sandy clay loam, 21 October 2016, leg. K.-T. Yong 9530 (KLU).
Weissia controversa, a member of the Pottiaceae with a cosmopolitan distribution, is here reported for the first time in Peninsular Malaysia. Although the species is frequently reported in temperate regions, it is rarely collected from within the Malesian region (Eddy, 1990; Touw, 1992). The species is readily distinguishable from most others in the Pottiaceae that occur in the region by its small size, very short stems (to almost stemless), long slender, linear-lanceolate leaves with strongly involute margins, and a shortly excurrent costa that ends in a colourless apiculus. The upper laminal cells are quadrate, and opaque owing to their densely papillose surfaces. In contrast, the basal laminal cells are short to long rectangular and translucent with smooth surfaces. Weissia controversa could only be confused with $W$. edentula Mitt., as both species share a very similar morphology and both are present in Peninsular Malaysia (Yong et al., 2013). However, the latter species is differentiated by having gymnostomous capsules, while the capsules in $W$. controversa always possess 16 erect, short peristome teeth.

31. Weissia squarrosa (Nees \& Hornsch.) Müll.Hal.

Contributors: G. Vončina and A. Stebel

Poland: Western Carpathians, Pogórze Ciężkowickie foothills, Moszczenica village, nearby settlement Poddaństwo, Księży Las forest, $49^{\circ}$ $43^{\prime} 03^{\prime \prime} \mathrm{N}, 21^{\circ} 05^{\prime} 13^{\prime \prime} \mathrm{E}, 365 \mathrm{~m}$ a.s.1., on dry, sandy soil in ditch at the margin of Abies alba forest, associated with Bryum rubens Mitt. and Ceratodon purpureus (Hedw.) Brid., 29 May 2016, leg. \& det. G. Vončina s.n., conf. A. Stebel (KRAM, SOSN).

Weissia squarrosa is a European endemic moss (Porley, 2008), with a suboceanic distribution (Smith, 2004). It occurs in almost all the countries of western Europe (Schnyder et al., 2004; Nieuwkoop, 2007; Sotiaux et al., 2007; Porley, 2008, Werner, 2011; Ros et al., 2013), Scandinavia (Nyholm, 1989), Latvia, Estonia and the south part of the Ural mountains (Ignatov et al., 2006), in the Balkans in Slovenia and Serbia (Ros et al., 2013) and in Romania (Ştefănuţ \& Goia, 2012). This species has also been observed in Israel (Ros et al., 2013). In central Europe W. squarrosa has been noted in Germany, Austria, Poland (Limpricht, 1890; Meinunger \& Schröder, 2007; Köckinger et al., 2016), Slovakia (Kubinská et al., 2001) and the Czech Republic (Kučera et al., 2012). Weissia squarrosa is considered to be a Threatened moss (category R) in Europe (Schumacker \& Martiny, 1995) and, in various categories, in many European countries (Hodgetts, 2015).

The history of the occurrence of Weissia squarrosa in Poland is confusing. It was reported from the present territory of Poland only in the 19th century. Its first occurrence, in the vicinity of Frankfurt (Oder), was mentioned by Itzigsohn (1848), but after the Second World War, Frankfurt was divided 
between Germany and Poland. The Polish, eastern part, is at present the independent town of Słubice, and it is unclear whether the collection was made in the western or eastern part of Frankfurt. The second Polish locality for the species was wrongly reported from the vicinity of Pyrnik village near Zielona Góra (Limpricht, 1874), where the specimens in fact were Weissia rostellata (Brid.) Lindb. (Limpricht, 1876). A third locality for $W$. squarrosa was in Wrocław (Limpricht, 1876), which until now has been the only certain locality for the species in Poland. In its newly discovered locality, the population of $W$. squarrosa was abundant, with numerous sporophytes.

32. Zygodon forsteri (Dicks.) Mitt.

Contributors: B. Papp and M. Sinigla

Hungary: Veszprém County, Balaton Upland region, Sátorma-tető at Szentbékkálla village, in a knot-hole of Quercus cerris L. tree, $46^{\circ} 54^{\prime} 00.2^{\prime \prime} \mathrm{N}$, $17^{\circ} 32^{\prime} 29.4^{\prime \prime} \mathrm{E}, 310 \mathrm{~m}$ a.s.1., 17 May 2016, leg. B. Papp and M. Sinigla s.n., det. B. Papp. (BP no.190742)

This atlantic-submediterranean species is a member of the Orthotrichaceae. It usually grows around knotholes or other hollows on beech trees where water runs down on the bark, and often on callus tissue. The species has a very disjunct distribution, and is rare and threatened all across Europe. It is Red-Listed in almost all countries where it occurs and Vulnerable (VU) according to the Red Data Book of European bryophytes (ECCB, 1995).

Zygodon forsteri is new to Hungary. The specimen was collected in a knot-hole on Quercus cerris, in a managed Quercus cerris / Quercus petraea forest, in the same habitat where another rare species, Anacamptodon splachnoides (Brid.) Brid. occurs. This is also a threatened species in Europe, and protected in Hungary. The aim of our study was to estimate the population size of this species; therefore trees with hollows were thoroughly investigated. While A. splachnoides has a quite large population occurring in the neighbouring oak forests on more than 60 Quercus cerris trees, Zygodon forsteri was detected on only one. The moss formed a $3 \times 3 \mathrm{~cm}$ patch with a few old capsules.

\section{Acknowledgments}

This work was supported by The Natural History Museum, London (BM). T. Kiebacher is grateful to H. Köckinger for determining the specimen of Schistidium grande. N. G. Hodgetts would like to thank Ron Porley for redetermining specimens of Grimmia dissimulata from Madeira. V. Sahu, A. K. Asthana and K. K. Rawat are grateful to the Director, CSIR-National Botanical Research Institute, Lucknow for encouragement and providing the facilities and the Council of Scientific and Industrial Research,
New Delhi for financial support (BSC-0106). Thanks are also due to the authorities of GWLS, Forest Department, Uttarakhand for providing permission and facilities to visit the area. Financial support from SAC, ISRO, Ahmadabad, India under project no. 3329 entitled 'Alpine ecosystem dynamics and impact of climate change in Indian Himalaya (PRACRITIII)' is also acknowledged.

K. Hassel and H. Weibull thank the Norwegian Biodiversity Information Centre who financed the project 'Bryophytes of poorly known habitats in Norway, a field survey' 61-10: 70184219. The research by J. Deme, A. Alegro, D. Kovács, D. Purger, V. Šegota and J. Csiky was supported by: 'TÁMOP 4.2.2.D-15/1/KONV-2015-0015 Környezetiparhoz kapcsolódó innovatív transz- és interdiszciplináris kutatói team fejlesztése a PTE tudományos bázisán’ (Hungary), Public Institution Nature Park Papuk (Croatia) and the work of Judit Deme was supported by the ÚNKP-16-2 New National Excellence Program of the Ministry of Human Capacities (Hungary). The work of V. Bakalin \& K. Klimova was supported by the grant from the Russian Foundation for the Basic Researches (15-34-20101). The research of M. V. Dulin was performed with the financial support of Project № AAAA-A16116021010241-9: «Vegetation structural and functional organization, diversity of flora, lichen- and mycobiota of southern part of the 'Yugyd va' national park» (2016-2018) and the Russian Foundation for Basic Research (Projects № 15-04-03479-a, № 16-44110167). Bryophyte investigations in Asturias by M. Infante and P. Heras have benefited from the Flora Briofítica Ibérica project (Ministerio de Ciencia y Tecnología: Universitat Autònoma de Barcelona 2014-2016 CGL2013-40624-P). The work of V. Fedosov was partly supported by Grant \# 1450-00029 'Scientific basis of the national biobankdepository of the living systems' (branch 'Plants') from Russian Science Foundation (RNF). Y.-J. Yoon, S. J. Park and B.-Y. Sun would like to express our deepest gratitude to the late Dr Benito C. Tan for correcting our English text and making valuable suggestions. The work of M. J. Cano and J. Guerra was carried out with financial support from the Spanish government (project CGL2015-64068-P cofinanced by FEDER). The contributions by R. Ochyra have been financed through the statutory fund of the W. Szafer Institute of Botany, Polish Academy of Sciences. He is also grateful to the curators at $\mathrm{BG}$ and $\mathrm{E}$ for organising the loan of specimens. The field work of M. Lebouvier and R. Ochyra on Îles Crozet was organised within the programme 136 ECOBIO of the French Polar Institute (IPEV). The contribution by V. Plášek is part of research projects of the Institute of Environmental Technologies, reg. 
No. CZ.1.05/2.1.00/03.0100, the National Feasibility Programme I of the Czech Republic Project LO1208 and SYNTHESYS project DE-TAF-4436. K. Baráth and P. Erzberger thank L. Meinunger and W. Schröder, Ludwigsstadt (Germany), for confirming the identity of Plagiothecium latebricola. The work of I. V. Czernyadjeva was carried out within the framework of the institutional research project (no. 01201255616) of the Komarov Botanical Institute of the Russian Academy of Sciences and partially supported by RFBR (grants no. 16-04-01156). T. Ezer, G. Uyar, M. Ören and M. Alataş gratefully acknowledge the financial support of the Turkish Scientific and Technical Research Council (TUBITAK, Project Number: 114Z337). S. Ştefănuţ acknowledges the support by project no. RO1567-IBB03/2017 through the Institute of Biology Bucharest of Romanian Academy.

Taxonomic Additions and Changes: Nil.

\section{References}

Afonina, O.M. 2004. Conspectus of moss flora of Chukotka. St Peterburg: Botanicheskiy Institut im. Komarova, Rossiyskaya Akademiya Nauk (in Russian)

Afonina, O.M. 2015. Mosses. In: N.V. Matveeva, ed. Plants and fungi of the polar deserts in the northern hemisphere. St. Petersburg: Komarove Botanical Institute, pp. 75-116 (in Russian).

Ahn, Y.S, Lee, B.Y., Nam, G.H., Yoon, Y.J. \& Choi, S.S. 2011 National list of species of Korea (moss, liverwort). Incheon: National Institute of Biological Resources.

Ahrens, M. 2004. Ulota macrospora (Bryopsida, Orthotrichaceae) im Nordschwarzwald. Carolinea, 62: 69-79.

Aleffi, M., Tacchi, R. \& Cortini Pedrotti, C. 2008. Check-list of the hornworts, liverworts and mosses of Italy. Bocconea, 22: 1-255.

Alegro, A., Papp, B., Szurdoki, E., Šegota, V., Šapić, I. \& Vukelić, J. 2014. Contributions to the bryophyte flora of Croatia III. Plitvička jezera National Park and adjacent areas. Studia Botanica Hungarica, 45: 49-65.

Amann, A., Köckinger, H., Reimann, M., Schröck, C. \& Zechmeister, H. 2013. Bryofloristische Ergebnisse der Mooskartierung in Vorarlberg. Stapfia, 99: 87-140.

Amann, J. 1933. Flore des mousses de la Suisse Vol. III-Revision et additions. Beiträge zur Kryptogamenflora der Schweiz, 7(2): I-XIII, 1-186.

Arcangeli, G. 1889. Sopra alcune epatiche raccolte in Calabria. Nuovo Giornale Botanico Italiano e Bolletino della Societa Botanica Italiano, 21: 535-7.

Armitage, E. 1910. Some Madeira Hepaticae. Journal of Botany, London, 48: 156-8.

Arts, T. 2005. A contribution to the bryophyte flora of Réunion (Mascarene Islands). Systematic and Geography of Plants, 75: $117-58$

Atherton, I., Bosanquet, S. \& Lawley, M. eds. 2010. Mosses and liverworts of Britain and Ireland - a field guide. Plymouth: British Bryological Society, p. 260

Bakalin, V.A. 2010. The distribution of bryophytes in the Russian Far East. Part. 1. Hepatics. Vladivostok: Publishing company of Far Eastern University (in Russian, English)

Bakalin, V.A., Pisarenko, O.Yu., Cherdantseva, V.Ya., Krestov, P.V. Ignatov, M.S. \& Ignatova, E.A. 2012. Bryophytes of Sakhalin. Vladivostok: Publishing company of Far Eastern University (in Russian, English)

Bastow, R.A. 1887. Tasmanian mosses. Papers and Proceedings of the Royal Society of Tasmania, 1886: 38-102.

Baur, W. 1893. Ulota macrospora Baur \& Warnst. nov. spec. Hedwigia, 32: 259-60.
Bednarek-Ochyra, H. 2014a A taxonomic assessment of Racomitrium steerei (Grimmiaceae, Musci) from Venezuela. Herzogia, 27: 141-6.

Bednarek-Ochyra, H. 2014b. On the identities of some neglected species of Grimmiaceae from Îles Kerguelen. Journal of Bryology, 36: 300-5

Bednarek-Ochyra, H. 2014c. Taxonomic status of two subantarctic species of Philonotis (Bartramiaceae, Musci). Cryptogamie, Bryologie, 35: 387-95.

Bednarek-Ochyra, H. 2015a. Nomenclatural entanglements associated with Racomitrium chlorocarpum (Grimmiaceae). Phytotaxa, 188(3): 153-61.

Bednarek-Ochyra, H. 2015b. Bucklandiella lamprocarpa (Musci, Grimmiaceae) in central and northern Andes. Cryptogamie, Bryologie, 36(1): 81-90.

Bednarek-Ochyra, H. 2015c. Early records of Racomitrium s. lat. (Grimmiaceae, Musci) in the southern hemisphere and the correct author citations for $R$. crispulum and $R$. rupestre. Cryptogamie, Bryologie, 36: 143-54.

Bednarek-Ochyra, H. \& Ochyra, R. 1996. Racomitrium curiosissimum (Musci, Grimmiaceae), an exquisite new species from New Zealand. Fragmenta Floristica et Geobotanica, 41: 973-84.

Bednarek-Ochyra, H. \& Ochyra, R. 1998. Racomitrium lamprocarpum (Müll. Hal.) Jaeg.-an addition to the moss flora of Îles Kerguelen and the Subantarctic. Journal of Bryology, 20(2): 525-8.

Bednarek-Ochyra, H. \& Ochyra, R. 2010. Bucklandiella allanfifei (Grimmiaceae), a new moss species from New Zealand, with a note on South American B. striatipila. Journal of Bryology, 32(4): 245-55.

Bednarek-Ochyra, H. \& Ochyra, R. 2011. Bucklandiella angustissima sp. nov. (Grimmiaceae), a new austral amphipacific species with the smallest capsules and the shortest setae in the genus. Cryptogamie, Bryologie, 32(1): 13-27.

Bednarek-Ochyra, H. \& Ochyra, R. 2012a. The taxonomic status of Racomitrium capense (Bryophyta, Grimmiaceae) from South Africa. Cryptogamie, Bryologie, 33(2): 97-106.

Bednarek-Ochyra, H. \& Ochyra, R. 2012b. A consideration of Bucklandiella (Bryophyta, Grimmiaceae) in South America, with a taxonomic re-assessment of Racomitrium looseri. Nova Hedwigia, 95: 153-63.

Bednarek-Ochyra, H. \& Ochyra, R. 2013. Diversity of Grimmiaceae subfam. Racomitrioideae in sub-Saharan Africa, including an addition of Bucklandiella striatipila to the moss flora of the continent. Cryptogamie, Bryologie, 34 (1): $3-12$.

Bednarek-Ochyra, H., Ochyra, R. \& Buck, W.R. 1999. The genus Racomitrium (Grimmiaceae) in Brazil, with the first report of R. subsecundum in South America. Brittonia, 51: 93-105.

Bednarek-Ochyra, H., Ochyra, R., Sawicki, J. \& Szczecińska, M. 2014. Bucklandiella seppeltii, a new species of Grimmiaceae from Australasia and its phylogenetic position based on molecular data. Turkish Journal of Botany, 38: 1214-28.

Bezgodov, A.G. \& Ignatova, E.A. 2013. Pohlia lutescens (Mielichhoferiaceae, Bryophyta) in Russia. Arctoa, 22: 107-10.

Biedermann, S. Müller, F. and Seifert, E. 2014 Neu- und Wiederfunde für die Moosflora Sachsens. Herzogia, 27(1): 215-9.

Birkenmajer, K., Ochyra, R., Olsson, I.U. \& Stuchlik, L. 1985. MidHolocene radiocarbon-dated peat at Admiralty Bay, King George Island (South Shetland Islands, West Antarctica). Bulletin of the Polish Academy of Sciences, Earth Sciences, 33: 7-13.

Bischler-Causse, H. 1989. Marchantia L. The Asiatic and Oceanic taxa. Bryophytorum Bibliotheca, 38: 1-317.

Blockeel, T.L, Duckett, J.G., Fernández, M.C., Hébrard, J.-P., Matcham, H.W., Porley, R.D., Ochyra, R., Bednarek-Ochyra, H., Soldán, Z. \& Townsend, C.C. 2002. New national and regional bryophyte records, 5. Journal of Bryology, 24(1): 88-91.

Blockeel, T.L, Chlebicki, A., Hájková, P., Hájek, M., Hradílek, Z., Kürschner, H., Ochyra, R., Parolly, G., Plášek, V., Quandt, D., Townsend, C.C. \& Vanderpoorten, A. 2006. New national and regional bryophyte records, 12. Journal of Bryology, 28 (1): $68-70$.

Blockeel, T.L., Bednarek-Ochyra, H., Ochyra, R., Garilleti, R., Glime, J.M., Lara, F., Mazimpaka, V., Rusińska, A., SchäferVerwimp, A., Shabbara, H.M., Söderström, L., Stebel, A., Townsend, C.C., Váňa, J., Yayintaş, Ö.T. \& Żarnowiec, J. 
2007. New national and regional bryophyte records, 17. Journal of Bryology, 29(4): 277-83.

Blom, H.H. 1996. A revision of the Schistidium apocarpum complex in Norway and Sweden. Bryophytorum Bibliotheca, 49: 1-333.

Blom, H.H. \& De Zuttere, P. 2002. Quelques Schistidium intéressants récoltés dans les Alpes françaises (Savoie et Hautes-Alpes) ainsi que suisses (Valais). Nowellia Bryologica, 23: 36-7.

Boudier, P. \& Pierrot, R. 1996. Au sujet d'Ulota macrospora Baur \& Warnst. (Musci, Orthotrichacées) en France. Bulletin de la Société Botanique du Centre-Ouest, 27: 517-22.

Brugués, M. 2007. Sphagnum contortum y Pohlia longicolla en Andorra. Boletín de la Sociedad Española de Briología, 30-31: 37-8.

Brugués, M. \& Ruiz, E. 2016. Leskeaceae. Hypnales: Fabroniaceae, Leskeaceae, Pterigynandraceae, Thuidiaceae. In: J. Guerra \& M. Brugués, coord. Flora Briofitica Ibérica (Fascículos). Murcia: Sociedad Española de Briología, pp. 11-27.

Bryophyte Specialist Group. 2000. Jamesoniella undulifolia. The IUCN Red List of Threatened Species 2000: e.T39199A10169513. http://dx.doi.org/10.2305/IUCN.UK 2000.RLTS.T39199A10169513.en

Casas, C. 2005. Catàleg de les molses d'Andorra. Orsis, 20: 41-59.

Casas, C., Brugués, M. \& Cros, R.M. 2003. Flora dels Briòfits dels Països Catalans. I. Molses. Barcelona: Institut d'Estudis Catalans.

Casas, C., Brugués, M., Cros, R.M. \& Sérgio, C. 2006. Hand-book of mosses of the Iberian Peninsula and Balearic Islands: illustrated keys to genera and species. Barcelona: Secció de Ciències Biològiques, Institut d'Estudis Catalans.

Chereshnev, I.A. ed. 2008. Red Data Book of the Chukchi Autonomous District. Vol. 2. Plants. Magadan: Wild North (in Russian).

Chopra, R.S. 1975. Taxonomy of Indian mosses. New Delhi: C.S.I.R. Publication

Costa, J.G. \& Persson, H. 1941. Briófitas do Porto Santo. Brotéria, Série Ciências Naturais, 10: 29-39.

Damsholt, K. 2002. Illustrated Flora of Nordic liverworts and hornworts. Lund: Nordic Bryological Society.

Dierßen, K. 2001. Distribution, ecological amplitude and phytosociological characterization of European bryophytes. Bryophytorum Bibliotheca, 56: 1-289.

Doroshina, G.Ya. 2012. New moss records from Republic of Kabardino-Balkaria. 4. In: E.V. Sofronova, ed. New bryophyte records. 4. Arctoa 21: 287-8 (in Russian).

Eckstein, J., Preussing, M. \& Thiel, H. 2015. Ergänzungen zur Moosflora Niedersachsens und Hessens. Herzogia, 28(1): 9-27.

Eddy, A. 1990. A handbook of Malesian mosses, Vol. II Leucobryaceae to Buxbaumiaceae. London: Natural History Museum.

Ellis, L.T., Alegro, A., Bansal, P., Nath, V., Cykowska, B., BednarekOchyra, H., Ochyra, R., Dulin, M.V., Erzberger, P., Garcia, C. Sérgio, C., Claro, D., Stow, S., Hedderson, T.A., Hodgetts, N.G., Hugonnot, V., Kučera, J., Lara, F., Pertierra, L. Lebouvier, M., Liepina, L., Mežaka, A., Strazdina, L., Madžule, L., Rēriha, I., Mazooji, A., Natcheva, R., Phephu, N., Philippov, D.A., Plášek, V., Cíhal, L., Pócs, T., Porley, R.D., Sabovljević, M., Salimpour, F., Behroozmand Motlagh, M., Sharifnia, F., Akhoondi Darzikolaei, S., Schäfer-Verwimp, A., Šegota, V., Shaw, A.J., Sim-Sim, M., Sollman, P., Spitale, D., Hölzer, A., Stebel, A., Váňa, J., van Rooy, J. \& Vončina, G. 2012a. New national and regional bryophyte records, 32. Journal of Bryology, 34(3): 231-46.

Ellis, L.T., Bednarek-Ochyra, H., Ochyra, R., Cykowska, B., Dulin, M.V., Ezer, T., Kara, R., Flores, J.R., Suárez, G.M., Garcia, C., Martins, A., Sérgio, C., Garilleti, R., Kirmaci, M., Agcagil, E., Kurbatova, L.E., Lebouvier, M., Papp, B., Szurdoki, E. Philippov, D.A., Plášek, V., Pócs, T., Sabovljević, M., Sawicki, J., Sim-Sim, M., Szücs, P., Bidló, A., Váňa, J., Vigalondo, B., Lara, F., Draper, I., Virchenko, V.M. \& Wolski, G.J. 2012b. New national and regional bryophyte records, 33. Journal of Bryology, 34(4): 281-91.

Ellis, L.T., Asthana, A.K., Gupta, R., Nath, V., Sahu, V., BednarekOchyra, H., Ochyra, R., Cykowska, B., Calvo Aranda, S. Fischer, E., Gabriel, R., Górski, P., Gremmen, N., Hespanhol, H., Kurbatova, L.E., Lewis Smith, R.I., Long, D.G., Bell, D. Mogro, F., Sérgio, C., Garcia, C.A., Stow, S., Martins, A., Smith, V.R., Váňa, J. \& Vanderpoorten, A. 2013a. New national and regional bryophyte records, 34. Journal of Bryology, 35(1) $62-70$.
Ellis, L.T., Bednarek-Ochyra, H., Ochyra, R., Benjumea, M.J., Saïs, L.V., Caparrós, R., Lara, F., Mazimpaka, V., Dulin, M.V., Garilleti, R., Gremmen, N., Grundling, P.-L., Heras, P., Infante, M., Huttunen, S., Ignatov, M.S., Korvenpää, T., Lebouvier, M., Lewis Smith, R.I., Lin, S.-H., Yang, J.-D., Linström, A., Plášek, V., Rosselló, J.A., Sawicki, J., van Rooy, J., Smith V.R. 2013b. New national and regional bryophyte records, 35. Journal of Bryology, 35(2): 129-39.

Ellis, L.T., Bakalin, V.A., Baisheva, E., Bednarek-Ochyra, H., Ochyra, R., Borovichev, E.A., Choi, S.S., Sun, B.-Y., Erzberger, P., Fedosov, V.E., Garilleti, R., Albertos, B., Górski, P., Hájková, P., Hodgetts, N.G., Ignatov, M., Koczur, A., Kurbatova, L.E., Lebouvier, M., Mežaka, A., Miravet, J., Pawlikowski, P., Porley, R.D., Rosselló, J.A., Sabovljević, M.S., Pantović, J., Sabovljević, A., Schröder, W., Ştefănuţ, S., Suárez, G.M., Schiavone, M., Yayintaş, Ö.T. \& Ván̆a, J. 2013c. New national and regional bryophyte records, 36 . Journal of Bryology, 35(3): 228-38.

Ellis, L.T., Afonina, O.M., Asthana, A.K., Gupta, R., Sahu, V., Nath, V., Batan, N., Bednarek-Ochyra, H., Benitez, A., Erzberger, P., Fedosov, V.E., Górski, P., Gradstein, S.R., Gremmen, N., Hallingbäck, T., Hagström, M., Köckinger, H., Lebouvier, M., Meinunger, L., Németh, C., Nobis, M., Nowak, A., Özdemir, T., Pantović, J., Sabovljević, A., Sabovljević, M.S., Pawlikowski, P., Plášek, V., Cíhal, L., Sawicki, J., Sérgio, C., Ministro, P., Garcia, C.A., Smith, V.R., Ştefănuţ, S., Stow, S., Suárez, G.M., Flores, J.R., Thouvenot, L., Váňa, J., van Rooy, J. \& Zander, R.H. 2014a. New national and regional bryophyte records, 39. Journal of Bryology, 36(2): 134-51.

Ellis, L.T., Aleffi, M., Asthana, A.K., Srivastava, A., Bakalin, V.A., Batan, N., Özdemir, T., Bednarek-Ochyra, H., Borovichev, E.A., Brugués, M., Cano, M.J., Choi, S.S., De Beer, D., Eckstein, J., Erzberger P., Fedosov, V.E., Ganeva, A., Natcheva, R., Garcia, C.A., Sérgio, C., Garilleti, R., Albertos, B., Puche, F., Gücel, S., Higuchi, M., Hugonnot V., Hylander, K., Kırmacı, M., Aslan, G., Koponen, T., Lara, F., Mazimpaka, V., van Melick, H., Müller, F., Özenoglu Kiremit, H., Papp, B., Szurdoki, E., Plášek, V., Cíhal, L., van der Pluijm, A., Poponessi, S., Mariotti, M.G., Reyniers, J., Sabovljević, M.S., Sawicki, J., Smith, V.R., Stebel, A., Stefănut, S., Sun, B.-Y., Váňa, J. \& Venanzoni, R. 2014b. New national and regional bryophyte records, 40. Journal of Bryology, 36(3): 223-44.

Ellis, L.T., Aleffi, M., Tacchi, R., Alegro, A., Alonso, M., Asthana, A.K., Sahu, V., Biasuso, A.B., Callaghan, D.A., Ezer, T., Kara, R., Seyli, T., Garilleti, R., Gil-López, M.J., GwynneEvans, D., Hedderson, T.A., Kiebacher, T., Larrain, J., Long, D., Lüth, M., Malcolm, B., Mamontov, Y.S., Newsham, K.K., Nobis, M., Nowak, A., Ochyra, R., Pawlikowski, P., Plášek, V., Cihal, L., Potemkin, A.D., Puche, F., Rios, D., Gallego, M.T., Guerra, J., Sawicki, J., Schäfer-Verwimp, A., SegarraMoragues, J.G., Segota, V., Sofronova, E.V., Stefănuț, S., Szücs, P., Bidló, A., Papp, B., Szurdoki, E., Tan, B.C., Váňa, J., Vigalondo, B., Draper, I., Lara, F., Yoon, Y.-J., Sun, B.-Y. \& Nishimura, N. 2014c. New national and regional bryophyte records, 41. Journal of Bryology, 36(4): 99-114.

Ellis, L.T., Aleffi, M., Bakalin, V.A., Bednarek-Ochyra, H., Bergamini, A., Beveridge, P., Choi, S.S., Fedosov, V.E., Gabriel, R., Gallego, M.T., Grdović, S., Gupta, R., Nath, V., Asthana, A.K., Jennings, L., Kürschner, H., Lebouvier, M., Nair, M.C., Manjula, K.M., Rajesh, K.P., Nobis, M., Nowak, A., Park, S.J., Sun, B.-Y., Plášek, V., Ć́hal, L., Poponessi, S., Mariotti, M.G., Sabovljević, A., Sabovljević, M.S., Sawicki, J., Schnyder, N., Schumacker, R., Sim-Sim, M., Singh, D.K., Singh, D., Majumdar, S., Singh Deo, S., Ştefănuţ, S., Suleiman, M., Seng, C.M., Chua, M.S., Váňa, J., Venanzoni, R., Bricchi, E. \& Wigginton, M.J. 2015a. New national and regional bryophyte records, 42. Journal of Bryology, 37(1): $68-85$

Ellis, L.T., Asthana, A.K., Srivastava, A., Bakalin, V.A., BednarekOchyra, H., Cano, M.J., Jiménez, J.A., Alonso, M., Deme, J., Csiky, J., Dia, M.G., Campisi, P., Erzberger, P., Garilleti, R., Gorobets, K.V., Gremmen, N.J.M, Jimenez, M.S., Suárez, G.M., Jukonienė, I., Kiebacher, T., Kırmacı, M., Koczur, A., Kürschner, H., Lara, F., Mazimpaka, V., Larraín, J., Lebouvier, M., Medina, R., Natcheva, R., Newsham, K.K., Nobis, M., Nowak, A., Ören, M., Özçelik, A.D., Orgaz, J.D., Peralta, D.F., Plášek, V., Cíhal, L., Ristow, R., Sawicki, J., Schäfer-Verwimp, A., Smith, V.R., Stebel, A., Stefănut, S., Subkaitè, M., Sun, B.-Y., Uselienè, A., Uyar, G., Váňa, J., 
Yoon, Y.-J. \& Park, S.J. 2015b. New national and regional bryophyte records, 43. Journal of Bryology, 37(2): 128-46.

Ellis, L.T., Asthana, A.K., Srivastava, P., Omar, I., Rawat, K.K. Sahu, V., Cano, M.J., Costa, D.P., Dias, E.M., Dias dos Santos, N., Silva, J.B., Fedosov, V.E., Kozhin, M.N., Ignatova, E.A., Germano, S.R., Golovina, E.O., Gremmen, N.J.M., Ion, R., Ştefănuţ, S., von Konrat, M., Jimenez, M.S., Suárez, G.M., Kiebacher, T., Lebouvier, M., Long, D.G., Maity, D., Ochyra, R., Parnikoza, I., Plášek, V., Fialová, L., Skoupá, Z., Poponessi, S., Aleffi, M., Sabovljević, M.S., Sabovljević, A.D. Saha, P., Aziz, M.N., Sawicki, J., Suleiman, M., Sun, B.-Y., Váňa, J., Wójcik, T., Yoon, Y.-J., Zarnowiec, J. \& Larraín, J. 2016a. New national and regional bryophyte records, 46 Journal of Bryology, 38: 47-63.

Ellis, L.T., Alataş, M., Asthana, A.K., Rawat, K.K., Sahu, V., Srivastava, A., Bakalin, V.A., Batan, N., Bednarek-Ochyra, H., Bester, S.P., Borovichev, E.A., De Beer, D., Enroth, J., Erzberger, P., Fedosov, V.E., Feuillet-Hurtado, C., Gradstein, S.R., Gremmen, N.J.M., Hedenäs, L., Katagiri, T., Yamaguchi, T., Lebouvier, M., Maity, D., Mesterházy, A., Müller, F., Natcheva, R., Németh, Cs., Opisso, J., Özdemir, T., Erata, H., Parnikoza, I., Plášek, V., Sabovljević, S., Sabovljević, A.D., Saha, P., Md Nehal Aziz, Schröder, W., Váňa, J., van Rooy, J., Wang, J., Yoon, Y.-J. \& Kim, J.H. 2016b. New national and regional bryophyte records, 47. Journal of Bryology, 38(2): 151-67.

Ellis, L.T., Aleffi, M., Alegro, A., Segota, V., Asthana, A.K., Gupta, R., Singh, V.J., Bakalin, V.A., Bednarek-Ochyra, H., Cykowska-Marzencka, B., Benitez, A., Borovichev, E.A., Vilnet, A.A., Konstantinova, N.A., Buck, W.R., Cacciatoro, C., Sérgio, C., Csiky, J., Deme, J., Kovács, D., Damsholt, K., Enroth, J., Erzberger, P., Fedosov, V.E., Fuertes, E., Gradstein, S.R., Gremmen, N.J.M., Hallingbäck, T., Jukonienè, I., Kiebacher, T., Larraín, J., Lebouvier, M., Lüth, M., Mamontov, Yu.S., Potemkin, A.D., Nemeth, Cs., Nieuwkoop, J.A.W., Nobis, M., Osorio, F., Parnikoza, I., Peralta, D.F., Carmo, D.M., Plášek, V., Skoupá, Z., Poponessi, S., Venanzoni, R., Puche, F., Purger, D., Reeb, C., Rios, R., Rodriguez-Quiel, E., Arrocha, C., Sabovljević, M.S., Nikolić, N., Sabovljević, A.D., dos Santos, E.L., Segarra-Moragues, J.G., Stefănut, S., Stončius, D., Virchenko, V.M., Wegrzyn, M. \& Wietrzyk, P. 2016c. New national and regional bryophyte records, 48. Journal of Bryology, 38(3): 235-59.

Ellis, L.T., Agcagil, E., Krrmacı, M., Aleffi, M., Bakalin, V.A., Bednarek-Ochyra, H., Cykowska-Marzencka, B., StryjakBogacka, M., Bojaca, G.F.P., Fantacelle, L.B., Araújo, C.A.T., Maciel-Silva, A.S., Bruno Silva, J., Calleja, J.A., Cano, M.J., Castillo Diaz, J., Gabriel, R., Dias dos Santos, N., Enroth, J., Erzberger, P., Garilleti, R., Hájek, M., Hedenäs, L., Heras, P., Infante, M., Kiebacher, T., Koczur, A., Krawczyk, R., Kučera, J., Lebouvier, M., Lüth, M., Mazimpaka, V., Vigalondo, B., Lara, F., Nagy, J., Németh, Cs., Kovács, A., Nobis, M., Wegrzyn, M., Wietrzyk, P., Norhazrina, N., Vanderpoorten, A., Nowak, A., Poponessi, S., Gigante, D., Venanzoni, R., Plášek, V., Rangel Germano, S., Schäfer-Verwimp, A., Sérgio, C., Claro, D., Garcia, C.A., Shirzadian, S., Akhoondi Darzikolaei, A., Stebel, A., Suleiman, M., Yong, K.-T., Virchenko, V.M., Vončina, G., Yoon, Y.-J., Choi, H.-G. \& Kim, J.H. 2016d. New national and regional bryophyte records, 49. Journal of Bryology, 38 (4): $327-47$

Ellis, L.T., Aleffi, M., Bednarek-Ochyra, H., Bakalin, V.A., Boiko, M., Calleja, J.A., Fedosov, V.E., Ignatov, M.S., Ignatova, E.A., Garilleti, R., Hallingbäck, T., Lönnell, N., Hodgetts, N., Kiebacher, T., Larraín, J., Lebouvier, M., Lüth, M., Mazimpaka, V., Vigalondo, B., Lara, F., Natcheva, R., Nobis, M., Nowak, A., Orgaz, J.D., Guerra, J., Pantović, J., Nikolić, N., Sabovljević, M.S., Sabovljević, A.D., Pisarenko, O.Yu., Plášek, V., Skoupá, Z., Poponessi, S., Privitera, M., Puglisi, M., Skudnik, M. \& Wang, Q.H. 2017. New national and regional bryophyte records, 51. Journal of Bryology, 39(2): 177-90.

European Committee for the Conservation of Bryophytes (ECCB) 1995. Red Data book of European bryophytes. Trondheim: ECCB.

Fedosov, V.E. \& Ignatova E.A. 2005. Bryophyte flora of the "Ledyanaya Bay" Key plot (Byrranga Range, Taimyr, Siberian Arctic). Arctoa, 14: 71-94

Fedosov, V.E. \& Ignatova E.S. 2006. The genus Pseudocrossidium R.S Williams (Pottiaceae, Musci) in Russia. Arctoa, 15: 203-10.
Fife, A. 1984. Records of new or otherwise interesting mosses in New Zealand, including a new species of Racomitrium. New Zealand Journal of Botany, 22: 1-6.

Frahm, J.-P. 1982. Grossdisjunktionen von Arealen Südamerikanischer und Afrikanischer Campylopus-Arten. Lindbergia, 8: 45-52.

Frahm, J.-P. \& Frey, W. 2004. Moosflora. 4. Auflage. Stuttgart: Verlag Eugen Ulmer.

Frisvoll, A.A. 1988. A taxonomic revision of the Racomitrium heterostichum group (Bryophyta, Grimmiales) in N. and C. America, N. Africa, Europe and Asia. Gunneria, 59: 5-289.

Frisvoll, A.A. \& Elvebakk, A. 1996. Bryophytes. In: A catalogue of Svalbard plants, fungi, algae and cyanobacteria. Norsk Polarinstitut Skrifter, 198: 57-172.

Gabriel, R., Homem, N., Couto, A., Aranda, S.C. \& Borges, P.A.V. 2011. Azorean bryophytes: a preliminary review of rarity patterns. Acoreana Suplemento, 7: 149-206.

Gangulee, H.C. 1978. Mosses of eastern India and adjacent regions. Fasc. 7, Calcutta: H.C. Gangulee.

Gao, C., Vitt, D.H. \& He, S. 1999. Dicranaceae. In: C. Gao, M.R. Crosby and S. He, eds. Moss flora of China, English Version. Vol. 1. Sphagnaceae-Leucobryaceae. Beijing \& New York: Science Press \& St Louis, MO: Missouri Botanical Garden Press, pp. $90-241$.

Geheeb, A. 1910. Bryologia Atlantica. Die Laubmoose der Atlantischen Inseln (unter Ausschluss der Europäischen und Arktischen Gebiete. Bibliotheca Botanica, 73: 1-73+ i-xx pls.

González-Mancebo, J.M., Romaguera, F., Ros, R.M., Patiño, J. \& Werner, O. 2008. Bryophyte flora of the Canary Islands: an updated compilation of the species list with an analysis of island distribution patterns in the context of the Macaronesian Region. Cryptogamie, Bryologie, 29(4): 315-57.

Gradstein, S.R. 2013. Afro-American hepatics revisited. Polish Botanical Journal, 58: 149-77.

Hallingbäck, T. 2002. Globally widespread bryophytes, but rare in Europe. Portugalia Acta Botanica, 20: 11-24.

Hans, F. 2004. Neue und seltene Arten aus der Familie der Orthotrichaceae (Musci) für Luxemburg-mögliche Indikatoren für einen Klimawechsel? Bulletin de la Société des Naturalistes Luxembourgeois, 105: 15-25.

Hassel, K. 2003. Acaulon mediterraneum Limpr. confirmed for Norway, with remarks on the redlisted A. muticum (Hedw.) Müll.Hal. Lindbergia, 28: 97-8.

Hassel, K. 2004. Moser i kulturlandskapet og registreringer i åkerkanter og beitemark i Tronfeimsfjordområdet. Direktoratet for naturforvaltning, utredning, 2004-5: 30.

Hattori, S. 1966. Bryophyta. In: H. Hara, ed. The flora of Eastern Himalaya. Tokyo: University of Tokyo, pp. 501-36.

Hedenäs, L. 1989. Amblystegium longicuspis Lindb. \& H. Arn., its status and taxonomic position. Lindbergia, 14: 142-6.

Hedenäs, L. 2014. Amblystegiaceae G. Roth. In: Flora of North America Editorial Committee, eds. Flora of North America. Vol. 28. Bryophytes: Mosses, Part 2. New York: Oxford University Press, pp. 263-319.

Herzog, T. 1934. Studien über Drepanolejeunea II. Annales Bryologici, 7: 57-94.

Hill, M.O. \& Preston, C.D. 1998. The geographical relationships of British and Irish bryophytes. Journal of Bryology, 20: 127-226.

Hill, M.O., Preston C.D. \& Smith A.J.E. 1994. Atlas of the bryophytes of Britain and Ireland, Vol. 3. Mosses (Diplolepideae). Colchester: Harley Books.

Hodgetts, N.G. 2015. Checklist and country status of European bryophytes-towards a new Red List for Europe. Irish Wildlife Manuals, 84. Dublin: National Parks and Wildlife Service, Department of Arts, Heritage and the Gaeltacht.

Hodgetts, N.G. \& Blockeel, T.L. 2014. Plagiothecium latebricola. In: T.L. Blockeel, S.D.S. Bosanquet, M.O. Hill, \& C.D. Preston, eds. Atlas of British and Irish Bryophytes. Vol. 2. Newbury: Pisces Publications, p. 572

Høitomt, T., Appelgren, L., Lönnell, N., Lye, K. \& Hassel, K. 2012. Pyramidula tetragona (Brid.) Brid. rediscovered in Fennoscandia and new to Norway. Lindbergia, 35: 33-9.

Hooker, J.D. 1867. Handbook of the New Zealand flora: a systematic description of the native plants of New Zealand and the Chatham, Kermadec's, Lord Auckland's Campbell's and Macquarrie's Islands, Part 2. London: Reeve \& Co., pp. xlixlvii + 393-798.

Ignatov, M.S., Afonina, O.M. \& Ignatova, E.A. 2006. Check-list of mosses of East Europe and North Asia. Arctoa, 15: 1-130. 
Infante Sánchez, M. 2015. Catalogue des bryophytes de la région Midi-Pyrénées. Bagnères de Biggore: Conservatoire botanique National des Pyrénées et Midi-Pyrénées, p. 115.

Ireland, R.R. 2014. Pseudotaxiphyllum Z.Iwatsuki. In: Flora of North America Editorial Committee, eds. Flora of North America north of Mexico. Vol. 28. Bryophyta, Part 2. New York-Oxford: Oxford University Press, pp. 559-61.

Ireland, R.R. \& Buck, W.R. 2009. Some Latin American genera of Hypnaceae (Musci). Smithsonian Contributions to Botany, 93: [1-8] + 1-97.

Itzigsohn, H. 1848. Ueber die Laubmoosflora der Mark Brandenburg. Flora, 31(14): 225-9.

Kaalaas, B. 1912. Bryophyten aus den Crozetinseln. II. Nyt Magazin for Naturvidenskaberne, 50: 97-119.

Kim, Y.H. \& Hwang, H.J. 1991. Korean spore-bearing plants. Vol. 8 Pyongyang: Science \& Encyclopedia (in Korean).

Köckinger, H., Suanjak, M., Schriebl, A. \& Schröck, C. 2008. Die Moose Kärntens. Klagenfurt: Verlag des Naturwissenschaftliche Verein für Kärnten.

Köckinger, H., Schröck, C., Krisai, R. \& Zechmeister, H.G. 2016. Checklist of Austrian bryophytes [accessed 12 March 2017] Available at: http://cvl.univie.ac.at/projekte/moose.

Konstantinova, N.A. 2004. Distribution patterns of the North Holarctic hepatics. Arctoa, 9: 29-4 (in Russian).

Konstantinova, N.A. \& Lapshina, E.D. 2014. On the hepatic flora of the eastern Subpolar Ural (Khanty-Mansi autonomous district). Arctoa, 23: 80-90 (in Russian)

Konstantinova, N.A., Bakalin, V.A., Andrejeva, E.N., Bezgodov, A.G., Borovichev, E.A., Dulin, M.V. \& Mamontov, Yu.S. 2009. Checklist of liverworts (Marchantiophyta) of Russia. Arctoa, 18: 1-64 (in Russian).

Kubinská, A., Janovicová, K. \& Šoltés, R. 2001. Aktualizovaný zoznam pečeňoviek, rožtekov a machov Slovenska. Updated checklist of liverworts, hornworts and mosses of Slovakia. Bryonora, 28: 4-10.

Kučera, J., Váňa, J. \& Hradílek, Z. 2012. Bryophyte flora of the Czech Republic: updated checklist and Red List and a brief analysis. Preslia, 84: 813-50.

Kürschner, H. \& Erdağ, A. 2005. Bryophytes of Turkey: an annotated reference list of the species with synonyms from the recent literature and an annotated list of Turkish bryological literature. Turkish Journal of Botany, 29: 95-154.

Kürschner, H. \& Frey, W. 2011. Liverworts, mosses and hornworts of Southwest Asia (Marchantiophyta, Bryophyta, Anthocerotophyta). Nova Hedwigia, Beiheft, 139: 1-240.

Lal, J. 2005. A checklist of Indian mosses. Dehra Dun: Bishen Singh Mahendra Pal Singh.

Limpricht, K.G. 1874. Neue Bürger der schlesischen Laubmossflora Hedwigia, 13(4): 62-3.

Limpricht, K.G. 1876. Nachträge zu den Laub- und Lebermoosen. In: F. Cohn, ed. Kryptogamen-Flora von Schlesien 1. Breslau J. U. Kern's Verlag (Max Müller), pp. 413-44.

Limpricht, K.G. 1890. Die Laubmoose Deutschlands, Oesterreichs und der Schweiz. In: Dr L. Rabenhorst's Kryptogamen-Flora von Deutschland, Oesterreich und der Schweiz. 2 Aufl. 4(1) Sphagnaceae, Andreaeaceae, Archidiaceae, Bryineae (Cleistocarpae, Stegoacarpae [Acrocarpae]). Leipzig: Verlag von Eduard Kummer.

Maier, E. 2002. Grimmia dissimulata E.Maier sp. nova, and the taxonomic position of Grimmia trichophylla var. meridionalis Müll.Hal. (Musci, Grimmiaceae). Candollea, 56: 281-300.

Maier, E. 2011. Key to Grimmia species in Europe. Field Bryology, 105: $12-31$.

McFarland, K.D. 1988. Revision of Brachythecium (Musci) for Mexico, Central America, South America, Antarctica, and circumSubantarctic Islands. Facsimile of the dissertation, The University of Tennessee, Knoxville. Ann Arbor: UMI Dissertation Services.

Meinunger, L. \& Schröder, W. 2007. Verbreitungsatlas der moose Deutschlands. Band 2. Regensburg: Herausgegeben von Oliver Dürhammer für die Regensburgischer Botanische Gesellschaft

Mirkin, B.N. ed. 2011. Red Data Book of the Bashkortostan Republic. Vol. 1. Plants and Fungi. Ufa: MediaPrint (in Russian).

Mitten, W. 1876a. The Musci and Hepaticae collected by H. N. Moseley, M. A., naturalist to H. M. S. 'Challenger'. Journal of the Linnean Society Botany, 15: 59-73.

Mitten, W. 1876b. A list of the Musci and Hepaticae collected in Kerguelen's Island by Rev. A. E. Eaton, A.M. Journal of the Linnean Society Botany, 15: 193-7.

Mitten, W. 1882. Australian mosses. Transactions and Proceedings of the Royal Society of Victoria, 19: 49-96.
Mizutani, M. 1970. Lejeuneaceae, subfamilies Lejeuneioideae and Cololejeuneoideae from Sabah (North Borneo). Journal of Hattori Botanical Laboratory, 33: 225-65.

Mueller, F. von. 1881. Addimenta pro supplemento voluminis undecimi. Musci. In: Fragmenta phytographiae Australiae. Volume 11 Supplementum 3. Melbourne, ex Officina Joannis Ferres, pp. 107-15.

Müller, F. 2009. An updated checklist of the mosses of Chile. Archive for Bryology, 58: 1-124.

Nath V., Asthana A.K. \& Sahu V. 2010. Enumeration of liverworts and mosses of Valley of Flowers (Garhwal Hills) Uttarakhand, India. Geophytology, 39(12): 49-63.

Nieuwkoop, J. 2007. Weissia squarrosa (Vertakt vliesjesmos) terug in Nederland. Buxbaumiella, 79: 8-10.

NISM. 2017. Online-Atlas der Schweizer moose. [accessed 10 January 2017]. Available at: www.nism.uzh.ch.

Noguchi, A. (supplemented by Iwatsuki, Z.) 1987. Illustrated Moss Flora of Japan, Part 1. Nichinan: Hattori Botanical Laboratory.

Nyholm, E. 1989. Illustrated Flora of Nordic Mosses. Fasc. 2. $\quad$ Pottiaceae-Splachnaceae-Schistostegaceae. Copenhagen and Lund: Nordic Bryological Society.

Ochyra, R. 1985a. Hypnobartlettia fontana gen. et sp. nov. (Musci: Hypnobartlettiaceae fam. nov.), a unique moss from New Zealand. Lindbergia, 11: 2-8.

Ochyra, R. 1985b. Koponenia, a new pleurocarpous moss genus from Bolivia. Journal of Bryology, 13(4): 479-86.

Ochyra, R. 1986. On the taxonomic position of Sciaromium lacustre Herz. \& Rich. in Rich. Journal of Bryology, 14(1): 109-15.

Ochyra, R. 1987. On the taxonomy and family placement of the moss genus Limbella (C. Muell.) Broth. Journal of Bryology, 14(3): 465-85.

Ochyra, R. 2010. Antipodal mosses: XVI. The first record of the genus Sematophyllum (Sematophyllaceae) in the Subantarctic, with a description of $S$. lebouvieri sp. nov. Cryptogamie, Bryologie, 31(3): 223-32

Ochyra, R. \& Bednarek-Ochyra, H. 2011. Schistidium deguchianum (Grimmiaceae), a new Andean species from Peru. Journal of Bryology, 33(3): 189-94.

Ochyra, R. \& Bednarek-Ochyra, H. 2013. On the identity of Ditrichum validinervium (Bryophyta, Ditrichaceae). Cryptogamie, Bryologie, 34(3): 299-306.

Ochyra, R. \& Lewis Smith, R.I. 1998. Antarctic species in the genus Ditrichum (Ditrichaceae, Bryopsida), with a description of $D$. gemmiferum sp. nov. Annales Botanici Fennici, 35(1): 33-53.

Ochyra, R. \& Vanderpoorten, A. 1999. Platyhypnidium mutatum, a mysterious new moss from Germany. Journal of Bryology, 21 (3): 183-9.

Ochyra, R. \& van Rooy, J. 2013. Distribution of Bucklandiella lamprocarpa (Grimmiaceae, Musci) in South Africa. Cryptogamie, Bryologie, 34: 359-66.

Ochyra, R., Sérgio, C. \& Schumacker, R. 1988. Racomitrium lamprocarpum (C. Muell.) Jaeg., an austral moss disjunct in Portugal, with taxonomic and phytogeographic notes. Bulletin du Jardin Botanique National de Belgique, 58: 225-58.

Ochyra, R., Bednarek-Ochyra, H., Pócs, T. \& Crosby, M.R. 1992. The moss Adelothecium bogotense in continental Africa, with a review of its world range. Bryologist, 95: 287-95.

Ochyra, R., Bednarek-Ochyra, H. \& Lewis Smith, R.I. 2002. New and rare moss species from subantarctic South Georgia. Nova Hedwigia, 74(1-2): 121-47.

Ochyra, R., Żarnowiec, J. \& Bednarek-Ochyra, H. 2003. Census catalogue of Polish mosses. Kraków: Polish Academy of Sciences, Institute of Botany.

Ochyra, R., Bednarek-Ochyra, H. \& Lewis Smith, R.I. 2008. New and rare moss species from the Antarctic. Nova Hedwigia, 87 (3-4): 457-77.

Ochyra, R., Zander, R.H. \& Lebouvier, M. 2014. Antipodal mosses: XVIII. Syntrichia christophei, a new species from subantarctic Îles Kerguelen. Cryptogamie, Bryologie, 35(1): 37-46.

Ochyra, R., Crabtree, D. \& Tangney, R. 2015. Studies on mosses in the Falkland Islands: I. Bucklandiella and Codriophorus (Grimmiaceae). Cryptogamie, Bryologie, 36(3): 289-310.

O'Shea, B.J. 2006. Checklist of the mosses of sub-Saharan Africa (version 5, 12/06). Tropical Bryology Research Reports, 6: 1-252. Available at: http://www.nhm.ac.uk/hosted_sites/ bbstbg/resources_lit_africa.html

Papp, B., Erzberger, P., Ódor, P., Hock, Zs., Szövényi, P., Szurdoki, E. \& Tóth, Z. 2010. Updated checklist and Red List of Hungarian bryophytes. Studia Botanica Hungarica, 41: 31-59. 
Papp, B., Alegro, A., Šegota, V., Šapić, I. \& Vukelić, J. 2013 Additions to the bryoflora of Croatia. Journal of Bryology, 35 (2): $140-3$.

Paris, É.G. 1897. Index bryologicus sive enumeratio muscorum hucusque cognitorum adjunctis synonyma distributioneque geographica locupletissimis. Part 1. PLA-RHY. Actes de la Société Linnéennee de Bordeaux, 51(or Série 6, Volume 1): $1-160$.

Park, G.W. \& Choi, K. 2007. New list of bryophytes in Korea. Gwangneung: Korean National Arboretum Korean Forest Service.

Pavletić, Z. 1955. Prodromus flore briofita Jugoslavije. Zagreb: Jugoslavenska akademija znanosti i umjetnosti.

Piippo, S. 1990. Annotated catalogue of Chinese Hepaticae and Anthocerotae. Journal of the Hattori Botanical Laboratory, 68: 1-192.

Pisarenko, O. Yu. 2007. New moss records from Altai Republic. 1. Arctoa, 16: 191

Poelt, J. 1955. Die Gipfelvegetation und -flora des Wettersteingebirges. Feddes Repertorium Specierum Novarum Regni Vegetabilis, 58: 157-79.

Poponessi, S., Aleffi, M. \& Venanzoni, R. 2014. Conocephalum salebrosum Szweykowski, Buczkowska et Odrzykoski (Conocephalaceae, Marchantiophyta), new to Italy. Cryptogamie, Bryologie, 35(2): 223-6.

Porley, R.D. 2004. Grimmia dissimulata E.Maier in Britain. Bulletin of the British Bryological Society, 82: 13-7.

Porley, R. 2008. Arable bryophytes. A field guide to the mosses, liverworts and hornworts of cultivated land in Britain and Ireland. Maidenhead: Wildguides.

Porley, R.D. 2016. A new key to British Grimmia in Britain and Ireland. Field Bryology, 116: 27-43.

Potemkin, A.D. \& Sofronova, E.V. 2009. Liverworts and hornworts of Russia. Vol. 1. Saint Petersburg-Yakutsk: Boston-Spectr. p. 368 (in Russian).

Preston, C.D. \& Bosanquet, S.D.S. 2014. Riccia glauca L. In: T.L. Blockeel, S.D.S. Bosanquet, M.O. Hill, \& C.D. Preston, eds. Atlas of British \& Irish Bryophytes. Vol. 1. Newbury: Pisces Publications, p. 80

Preston, C.D., Hill, M.O., Porley, R.D. \& Bosanquet, S.D.S. 2010 Survey of the bryophytes of arable land in Britain and Ireland 1: a classification of arable field assemblages. Journal of Bryology, 32(1): 61-79.

Rabenhorst, L. 1848 . Deutschlands Kryptogamenflora oder Handbuch zur Bestimmung der kryptogamischen Gewächse Deutschlands, der Schweiz, des lombardisch-venezianischen Königreichs und Istriens. 2. Leipzig: Eduard Kummer.

Ramsay, H.P., Klazenga, N., Ando, H. \& Iwatsuki, Z. 2012 Australian Mosses Online 58. Hypnaceae. Canberra: Australian Biological Resources Study. Version 17 July 2012. http://www.anbg.gov.au/abrs/Mosses_online/58_Hypnaceae. html.

Redfearn, P.L., Tan, B.C. \& Si, H. 1996. A newly updated and annotated checklist of Chinese mosses. Journal of the Hattori Botanical Laboratory, 79: 163-357.

Rintanen, T. 1996. Changes in the flora and vegetation of 113 Finnish lakes during 40 years. Annales Botanici Fennici, 33: 101-22.

Ros, R.M., Mazimpaka, V., Aleffi, M., Blockeel, T.L., Cano, M.J., Cros, R.M., Dia, M.G., Dirkse, G.M, Saadawi, W.El., Ganeva, A., González-Mancebo, J.M., Herrnstadt, I., Khalil, K., Kürschner, H., Lanfranco, E., Losada-Lima, A., Refai, M.S., Rodríguez-Nuñez, S., Sabovljević, M., Sérgio, C., Shabbara, H., Sim-Sim, M. \& Söderström, L. 2007. Hepatics and Anthocerotes of the Mediterranean, an annotated checklist. Cryptogamie, Bryologie, 28(4): 351-437.

Ros, R.M., Mazimpaka, V., Abou-Salama, U., Aleffi, M., Blockeel, T.L., Brugués, M., Cros, R.M., Dia, M.G., Dirkse, G.M., Draper, I., El-Saadawi, W., Erdağ, A., Ganeva, A., Gabriel, R., González-Mancebo, J.M., Granger, C., Herrnstadt, I., Hugonnot, V., Khalil, K., Kürschner, H., Losada-Lima, A., Luís, L., Mifsud, S., Privitera, M., Puglisi, M., Sabovljević, M., Sérgio, C., Shabbara, H.M., Sim-Sim, M., Sotiaux, A., Tacchi, R., Vanderpoorten, A. \& Werner, O. 2013. Mosses of the Mediterranean, an annotated checklist. Cryptogamie, Bryologie, 34(2): 99-283.

Sabovljević, M. 2003. The hepatic check list of Croatia. Archives of Biological Sciences, 55: 59-66.

Sabovljević, M. \& Natcheva, R. 2006. Check list of the liverworts and hornworts of south-eastern Europe. Phytologia Balcanica, 12 (2): $169-80$
Sainsbury, G.O.K. 1955. A handbook of New Zealand mosses. Royal Society of New Zealand Bulletin, 5: 1-490.

Sauer, M. 1998. Ulota macrospora, eine verkannte Art? Ein Beitrag zur Taxonomie der Gattung Ulota (Orthotrichaceae) in Mitteleuropa. Herzogia, 13: 37-51.

Schlüsslmayr, G. 2005. Soziologische Moosflora des südöstlichen Oberösterreich. Stapfia, 84: 1-695.

Schnyder, N., Bergamini, A., Hofmann, H., Müller, N., SchubigerBossard, C., \& Urmi, E. 2004. Rote Liste der gefährdeten Moose der Schweiz. Bern: BUWAL, pp. 1-99.

Schröck, C., Köckinger, H., Amann, G. \& Zechmeister, H. 2013. Rote Liste gefährdeter Moose Vorarlbergs. Dornbirn: inaturaErlebnis Naturschau.

Schumacker, R. \& Martiny, P. 1995. Red Data Book of European bryophytes. Part. 2: Threatened bryophytes in Europe including Macaronesia. Trondheim: The European Committee for Conservation of Bryophytes, pp. 29-193.

Schumacker, R. \& Váňa, J. 2005. Identification keys to the liverworts and hornworts of Europe and Macaronesia (Distribution and Status). 2nd edn. Poznań: Sorus.

Seppelt, R.D. 2004. The moss flora of Macquarie Island. Kingston: Australian Antarctic Division.

Sérgio, C., Muñoz, J. \& Ochyra, R. 1995. Racomitrium hespericum Sérgio, Muñoz \& Ochyra, a new species from the Iberian Peninsula. Bryologist, 98(1): 112-7.

Sérgio, C., Sim-Sim, M. \& Carvalho, M. 2006. Annotated catalogue of Madeiran bryophytes. Boletim do Museu Municipal do Funchal, 10: 5-164.

Singh, D.K., Singh, S.K. \& Singh, D. 2016. Liverworts and hornworts of India. An annotated checklist. Kolkata: Botanical Survey of India.

Smith, A.J.E. 2004. The moss flora of Britain and Ireland. 2nd edn. Cambridge: Cambridge University Press.

Söderström, L., Gradstein, S.R. \& Hagborg, A. 2010. Checklist of the hornworts and liverworts of Java. Phytotaxa, 9: 53-149.

Sotiaux, A., Stieperaere, H. \& Vanderpoorten, A. 2007. Bryophyte checklist and European Red List of the Brussels-Capital Region, Flanders and Wallonia (Belgium). Belgian Journal of Botany, 140(2): 174-96.

Spence, J.R. 2015. Gemmabryum gemmiferum (R.Wilczek \& Demaret) J.R.Spence. Flora of North America, Vol. 28: 135, http://www.efloras.org/florataxon.aspx?flora_id=1\&taxon_ id $=250099121$.

Spitale, D. \& Mair, P. 2017. Predicting the distribution of a rare species of moss: the case of Buxbaumia viridis (Bryopsida, Buxbaumiaceae). Plant Biosystems, 151: 9-19.

Srivastava, S.C., Shaheen, F. and Sharma, D. 1995. Notes on some rare and interesting liverworts from Eastern Himalaya. In: S.S. Kumar, ed. Recent studies on Indian Bryophytes. Dehradun: Bishen Singh Mahendra Pal Singh, pp. 65-74.

Ştefănut, S. \& Goia, I. 2012. Checklist and Red List of bryophytes of Romania. Nova Hedwigia, 95(1-2): 59-104.

Streimann, H. \& Klanzenga, N. 2002. Catalogue of Australian mosses. Canberra: Australian Biological Resources Study.

Takaki, N. 1964. A revision of Japanese Dicranum. Journal of the Hattori Botanical Laboratory, 27: 73-123.

Touw, A. 1992. A survey of the mosses of the Lesser Sunda Islands (Nusa Tenggara), Indonesia. Journal of Hattori Botanical Laboratory, 71: 289-366.

Townsend C. C. 1998. Oligotrichum glaciale sp. nov. and other new moss records from Kashmir. Journal of Bryology, 20(1): 51-63.

Uyar, G. \& Cetin, B. 2004. A new check-list of the mosses of Turkey. Journal of Bryology, 26(3): 203-20.

Uyar, G. \& Ören, M. 2013. Three remarkable new moss records for south-west Asia from northern Turkey. Turkish Journal of Botany, 37: 363-8.

Van der Putten, N., Stieperaere, H., Verbruggen, C. \& Ochyra, R. 2004. Holocene palaeoecology and climate history of South Georgia (sub-Antarctica) based on a macrofossil record of bryophytes and seeds. Holocene, 14: 382-92.

Van der Putten, N., Verbruggen, C., Ochyra, R., Spassov, S., de Beaulieu, J.-L., De Dapper, M., Hus, J. \& Thouveny, N. 2009. Peat bank growth, Holocene palaeoecology and climate history of South Georgia (sub-Antarctica), based on a botanical macrofossil record. Quaternary Science Reviews, 28: 65-79.

Van der Putten, N., Verbruggen, C., Ochyra, R., Verleyen, E. \& Frenot, Y. 2010. Subantarctic flowering plants: pre-glacial survivors or post-glacial immigrants? Journal of Biogeography, 37: $582-92$. 
Vohra, J.N. 1983. Hypnobryales suborder Leskeinae (Musci) of the Himalayas. Calcutta: Botanical Survey of India.

Werner, J. 2011. Les bryophytes du Luxembourg. Liste annotée et atlas. The bryophytes of Luxembourg - annotated list and atlas. Ferrantia, 65: 1-138.

Wigginton, M.J. 2012. Mosses and liverworts of St Helena. Newbury: Pisces Publications.

Wilczek, R. \& Demaret, F. 1976. Les espèces belges du "complexe Bryum bicolor" (Musci). Bulletin du Jardin botanique National de Belgique, 46: 511-41.

Yamada, K. 1979. A revision of Asia taxa of Radula, Hepaticae. Journal of the Hattori Botanical Laboratory, 45: 201-322.

Yamada, K. \& Choe, D.M. 1997. A checklist of Hepaticae and Anthocerotae in the Korean peninsula. Journal of the Hattori Botanical Laboratory, 81: 281-306.

Yamada, K. \& Iwatsuki, Z. 2006. Catalog of the hepatics of Japan. Journal of the Hattori Botanical Laboratory, 99: 1-106.
Yong, K.T., Tan, B.C., Ho, B.C., Ho, Q.Y. \& Mohamed, H. 2013. A revised moss checklist of Peninsular Malaysia and Singapore. FRIM Research Pamphlet 133. Kuala Lumpur: Forest Research Institute of Malaysia.

Zander, R.H. 2007. Pseudocrossidium. In: Flora of North America Editorial Committee, eds. Flora of North America north of Mexico. Vol. 27. Bryophyta, part 1. New York \& Oxford: Oxford University Press, pp. 569-72.

Zanten, B.O. van. 1971. Musci. In: E.M. van Zinderen Bakker sr., J.M. Winterbottom \& R.A. Dyer, eds. Marion and Prince Edward Islands. Report on the South African Biological and Geological Expedition 1965-1966. Cape Town: A. A. Balkema, pp. 173-227.

Zhang, M.-X. \& He, S. 2005. Hypnaceae. In: P-Ch. Wu, M.R. Crosby \& S. He, eds. Moss flora of China. English version. Volume 8. Sematophyllaceae-Polytrichaceae. BeijingNew York: Science Press and St. Louis: Missouri Botanical Garden Press, pp. 80-260. 